\title{
Acute and Chronic Respiratory Failure in Cancer Patients
}

\author{
Steven P. Sears, Gordon Carr, and Christian Bime
}

\section{Contents}

Introduction $\ldots \ldots \ldots \ldots \ldots \ldots \ldots \ldots \ldots \ldots \ldots \ldots \ldots \ldots \ldots \ldots \ldots \ldots \ldots \ldots \ldots \ldots \ldots \ldots \ldots \ldots, 2$

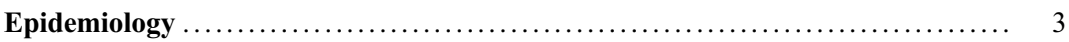

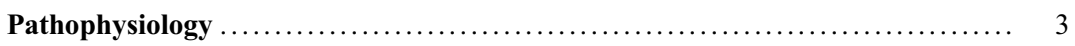

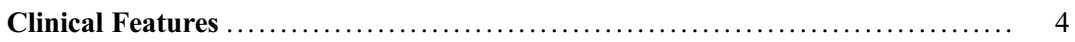

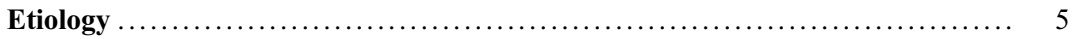

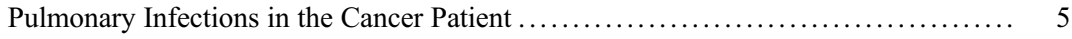

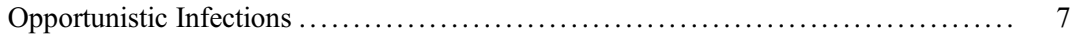

Fungal Pneumonia ............................................... 8

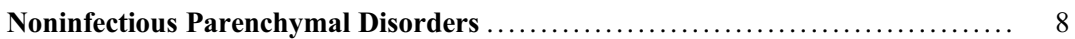

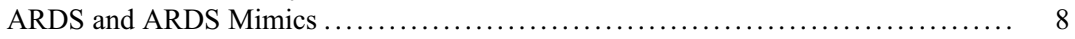

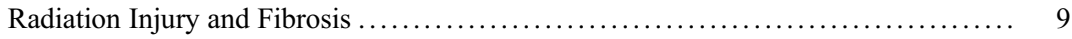

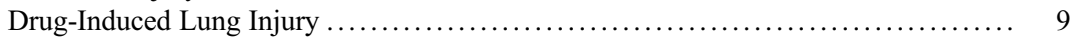

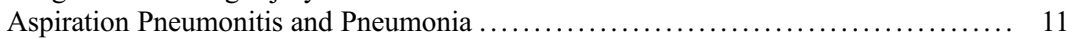

Transfusion-Related Acute Lung Injury and Circulatory Overload (TRALI/TACO) . . 11

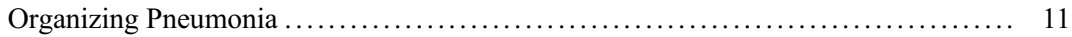

Parenchymal Disorders Common to HCT Patients .......................... 11

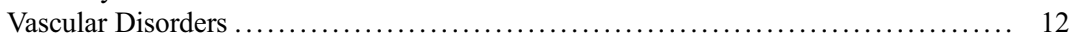

Cardiac Causes of Acute Respiratory Failure ............................ 13

\section{S. P. Sears}

Pulmonary and Critical Care Medicine,

University of Arizona, Tucson, AZ, USA

e-mail: ssears@deptofmed.arizona.edu

G. Carr

Banner-University Medical Center Tucson, Tucson, AZ,

USA

e-mail: Gordon.Carr@bannerhealth.com;

gcarr@deptofmed.arizona.edu

C. Bime $(\bowtie)$

University of Arizona School of Medicine and Banner-

University Medical Center - Tucson,

Tucson, AZ, USA

e-mail: cbime@deptofmed.arizona.edu 


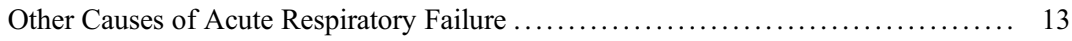

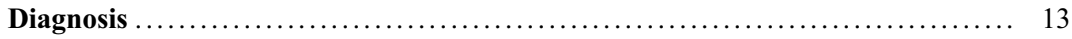

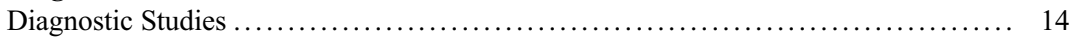

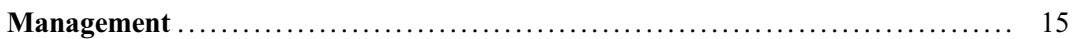

Noninvasive Positive Pressure Ventilation and High-Flow Nasal Oxygenation ....... 16

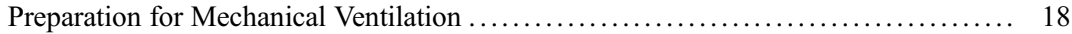

Treatment Strategies for Hypercapnic Respiratory Failure $\ldots \ldots \ldots \ldots \ldots \ldots \ldots \ldots \ldots \ldots$

Ventilatory Therapies for Hypoxemic Respiratory Failure $\ldots \ldots \ldots \ldots \ldots \ldots \ldots \ldots \ldots \ldots \ldots$

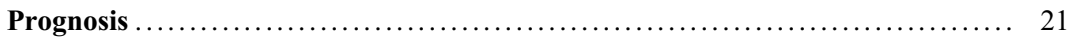

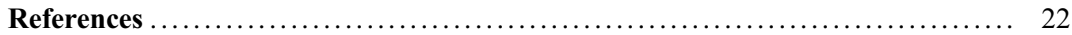

\section{Abstract}

In 2016, there was an estimated 1.8 million new cases of cancer diagnosed in the United States. Remarkable advances have been made in cancer therapy and the 5-year survival has increased for most patients affected by malignancy. There are growing numbers of patients admitted to intensive care units (ICU) and up to $20 \%$ of all patients admitted to an ICU carry a diagnosis of malignancy. Respiratory failure remains the most common reason for ICU admission and remains the leading causes of death in oncology patients. There are many causes of respiratory failure in this population. Pneumonia is the most common cause of respiratory failure, yet there are many causes of respiratory insufficiency unique to the cancer patient. These causes are often a result of immunosuppression, chemotherapy, radiation treatment, or hematopoietic stem cell transplant (HCT). Treatment is focused on supportive care and specific therapy for the underlying cause of respiratory failure. Noninvasive modalities of respiratory support are available; however, careful patient selection is paramount as indiscriminate use of noninvasive positive pressure ventilation is associated with a higher mortality if mechanical ventilation is later required. Historically, respiratory failure in the cancer patient had a grim prognosis. Outcomes have improved over the past 20 years. Survivors are often left with significant disability.

\section{Keywords}

Respiratory failure Noninvasive ventilation Mechanical ventilation - Intensive Care Unit · Diffuse alveolar hemorrhage $\cdot$ Organizing pneumonia $\cdot$ Pulmonary embolism $\cdot$ High resolution computed tomography ·

Bronchoscopy

\section{Introduction}

In 2016, an estimated 1.8 million new cases of cancer were diagnosed and 595,690 cancerrelated deaths in the United States [176]. In the United States, malignancy remains the second leading cause of death behind heart disease and has surpassed heart disease as the primary cause of death in those 45-79 years of age [155]. Worldwide there were 17.5 million new cancer diagnoses in 2015 [139]. With continued population growth, the number new cancer cases are expected to exceed 26 million by 2030 [174].

Despite the growing burden of cancer incidence, prevalence, and associated morbidity, remarkable advances have been made in cancer therapy. Until 1997, cancer deaths had been increasing for 70 years [155]. In 1969 the cumulative 5-year survival for patients with breast cancer was $64 \%$ [157]. Today with improvements in screening, precision medicine, anticancer agents, and treatment of side effects, $90 \%$ of patients with breast cancer will survive at least 5 years [155]. Likewise, over the last 50 years, 
5-year survival in younger patients with acute leukemia has increased from $4 \%$ to $60 \%$ [142]. In essence, the paradigm of cancer has shifted from stigmatized terminal illness, to that of chronic disease.

Paralleling this, recent studies have documented progress in the care of critically ill cancer patients $[11,14,26]$. With an aging population and more patients surviving with cancer, there are growing numbers of patients admitted to intensive care units [127]. In fact, $20 \%$ of patients admitted to intensive care units (ICU) carry a diagnosis of malignancy [169]. Nearly $10 \%$ of cancer patients will at some point be afflicted with a life-threatening condition justifying ICU admission [14, 32]. The most common reason for transfer to a critical care ward is organ failure [134, 162]. Acute organ failure may be related to co-morbid illness, cancer treatment, or the malignancy itself. Any organ may be affected, yet respiratory failure is the most frequent and most feared indication for ICU admission $[133,162]$.

Historically, respiratory failure remains the leading cause of death of critically ill cancer patients, especially those requiring mechanical ventilation [11, 16, 159]. Twenty years ago, mechanical ventilation of the bone marrow transplant patient portended almost certain death [59]. Recent advances in both neoplastic therapies and intensive care medicine have improved outcomes in patients with solid tumors, hematologic malignancies, and those undergoing bone marrow transplant (HCT) [13].

This chapter reviews the numerous causes of acute and chronic respiratory failure that occur in patients with solid and hematologic malignancies. The importance of expeditious diagnostic precision is reviewed in the context of the outcomes of respiratory failure. The increased use of high resolution computer tomography (HRCT) has greatly aided in narrowing the differential diagnosis of respiratory failure in oncology patients which leads to more efficient use of invasive diagnostic modalities. We will review some classic patterns on HRCT that suggest specific diagnoses with a high sensitivity and specificity. In terms of management, we review the literature on the utility and risks of invasive mechanical ventilation in immunocompromised cancer patients and further discuss the impact of current noninvasive ventilation strategies in this population. Finally, we will offer a general approach to diagnosis and management of respiratory failure in patients with active malignancy.

\section{Epidemiology}

Even in the absence of malignancy, acute and chronic respiratory failure have a high burden on patients, their families, and the health care system. In general the number of cases of acute respiratory failure is on the rise. In 2009 there were 1,917,910 cases of ARF in the United States resulting in 381,155 deaths and in inpatient cost of 54 billion dollars [166]. This translated into 784 cases of respiratory failure per 100,000 people, or an incidence of $0.7 \%$ [166]. Respiratory failure occurs in $5 \%$ of patients with solid tumors, $20 \%$ in those with hematologic malignancies, and in up to $50 \%$ of those undergoing bone marrow transplant [42]. For those cancer patients that survive respiratoryrelated critical illness, the estimated cost per year of life gained is nearly 83,000 dollars for patients with solid tumors and 189,000 dollars for patients with hematologic malignancy [151]. This figure is projected to increase with the use of novel antineoplastic treatments such as adoptive cell therapy with chimeric antigen receptor redirected T-cells (CAR-T) as such therapy itself is associated with a price tag of over 400,000 dollars [19]. Short term survival of respiratory related critical illness in cancer patients has improved. However, the effects of chronic respiratory complications remain unclear.

\section{Pathophysiology}

Respiratory failure is insufficient gas exchange due to derangements in one more components of the respiratory system including the central nervous system, chest wall and diaphragm, airways, alveolar-capillary interface, or pulmonary circulation. Depending on the nature of the insult, failure 
of the respiratory system may be acute, subacute, or chronic. Respiratory failure may be further characterized by physiologic imbalance, each of which portends numerous differential diagnosis. Type I respiratory failure or hypoxemia is characterized by persistently low partial pressure of oxygen $\left(\mathrm{PaO}_{2}\right.$ less than $\left.60 \mathrm{mmHg}\right)$. Hypercapnic respiratory failure (type II) is characterized by an arterial partial pressure of carbon dioxide greater than $45 \mathrm{mmHg}$. Type III respiratory failure is that associated with perioperative complications, while type IV respiratory failure relates to mismatch of oxygen consumption and delivery related to shock states.

Respiratory failure mediated by arterial hypoxemia has numerous general causes including malperfusion, hypoventilation, mismatch of ventilation and perfusion, defect in gas transfer across the alveolar-capillary interface, and anatomic or physiologic shunt of blood flow from venous to arterial circulation. Any of these general derangements may precipitate hypoxemia and tissue hypoxia.

In the absence of significant anatomic shunt, the pulmonary capillary bed receives the entirety of the cardiac output. This large blood volume makes the lungs a target for metastatic and thromboembolic disease. The fragile lattice of the capillary bed as well as the pulmonary interstitium is also sensitive to the collateral damage of radiation and the cytokine storm associated with systemic chemotherapy. These cancer therapies are also frequently toxic to the cardiovascular system resulting in pericardial effusion or cardiogenic pulmonary edema. Local spread of disease may complicate the proximal airways leading to respiratory distress and postobstructive complications of endobronchial lesions. Procedural removal of such lesions or metastatic spread may also interfere with the neurologic pathways responsible for respiratory mechanics. In addition, cancer itself and many chemotherapy regimens ablate the immune systems leading to a multitude of infectious complications.

Patients with cancer often have multisystem comorbidities that may contribute to respiratory failure. For example, not only does smoking predispose to the development of lung cancer but is also fundamental to the pathophysiology of emphysema, pulmonary fibrosis, coronary artery disease, and more. Many of these preexisting comorbidities may themselves precipitate ARF.

\section{Clinical Features}

The clinical features of acute and chronic respiratory failure are nonspecific, evident in multiple systems, and are dependent on the underlying disease state. For example, patients with ventilatory failure and hypercapnia may be moribund, somnolent, or simply confused. They may be tachypnic with pursed lip breathing due to obstructive lung disease, or hypopnic with pinpoint pupils or other exam findings suspect of narcotic toxidromes. Myoclonus and asterixis may be observed with carbon dioxide narcosis. Respiratory acidosis may predispose to instability in the cardiac sarcolemma with resultant arrhythmias.

Evidence of hypoxemia may be gleaned in nearly every bodily system. Neurologic manifestations include restlessness, confusion, myoclonus, and seizures. Hypoxemia and global tissue hypoxia may create an acidotic intracellular milieu which may instigate tachy or bradyarrhythmias. Local pulmonary findings reflect the causal insult. For example, use of accessory muscles of respiration, diminished air movement, diffuse wheezing, and tripoding are evident in the asthmatic with impending respiratory collapse. Stridor may indicate proximal airway narrowing due to malignant disease within the trachea. Dullness to percussion and reduced tactile fremitus raise suspicion for a pleural effusion or consolidative process. Resonance on percussion and trachea shift suggest pneumothorax. Inspiratory "Velcro"-like crackles could suggest fibrotic lung disease, and with the appropriate historical context, might indicate radiation induced lung injury. Digital clubbing may indicate primary lung cancer [149]. In severe hypoxia, cyanosis can be found around the lips, nail beds, and mucous membranes.

Classic findings of pleuritic chest pain and productive cough may not be evident in the cancer 
patient. Rather, nonspecific symptoms of fever and malaise may herald the development of pneumonia in this population.

Adaptations to chronic hypoxia manifest as polycythemia, headaches, and potentially right heart failure from cor pulmonale.

\section{Etiology}

The causes of respiratory dysfunction requiring ICU admission are similar in those with and without cancer. However, cancer predisposes patients to etiologies of ARF not always common in the general populace. The numerous causes of respiratory failure in critically ill cancer patients are demonstrated in Table 1. Common causes include infections, exacerbation of underlying comorbid illness, aspiration pneumonia, thromboembolic disease, cardiogenic pulmonary edema, noncardiogenic pulmonary edema from acute respiratory distress syndrome (ARDS), progression of malignancy, and complications of antineoplastic therapy. Numerous chemotherapeutic agents are associated with various forms of pulmonary toxicity. In addition, the use of stereotactic body radiation therapy has increased in the last two decades. This has translated to an increased incidence of radiation pneumonitis [188].

In general, the most common reason for respiratory failure in patients with cancer remains infection. However, there are also conditions that are unique to certain disease states. For example, patients with Acute Myeloid Leukemia (AML) are subject to leukostasis, while those who have undergone bone marrow transplant (BMT) are at risk for diffuse alveolar hemorrhage, idiopathic pneumonia syndrome, and more.

\section{Pulmonary Infections in the Cancer Patient}

Pneumonia is the most common infection in cancer patients [143]. Malignancy and chemotherapy both convey varying degrees of immunosuppression which in turn predispose to the development of infectious pneumonitis. The type of immune defect, humoral, cell-mediated, or qualitative granulocyte dysfunction, commonly influences microorganisms which breach host defenses. For example, defects in B-cell number or function as seen in acute leukemia and multiple myeloma predispose patients to infection with gram negative and encapsulated bacteria. Lymphoma or prolonged corticosteroid use may deplete T-cells leading to impairment in cell-mediated defense. Common infections in such patients include endemic mycosis and other fungal pathogens such as pneumocystis and Cryptococcus, mycobacteria, and viruses (especially CMV). Myeloproliferative disorders or the ablative effects of various chemotherapy may induce neutropenia leading one to be susceptible to virulent gram positive and negative bacteria, as well as opportunistic fungi including Aspergillus.

\section{Bacterial Pneumonia}

Bacterial pneumonia is the most common infection in the oncology patient predisposing to acute respiratory failure. In a cohort of 424 cancer patients with respiratory failure of determined etiology, bacterial pneumonia was diagnosed in $47 \%$. Of these, the classic community acquired pathogens accounted for $25 \%$. Streptococcus pneumonia was most frequently diagnosed. This followed by other streptococci, and more virulent and often resistant health care associated organisms such as Staphylococcus aureus (7.5\%), Pseudomonas aeruginosa (16\%), Enterobacter cloacae (10\%), and Klebsiella pneumonia (4\%). Ten percent culture positive pneumonia was documented due to intracellular organisms such as Legionella pneumophilia (5\%), Mycoplasma pneumonia (2.5\%), Coxiella burnetii (1\%), and Chlamydia pneumoniae [153].

\section{Viral Pneumonia}

Seasonal respiratory viruses are often implicated as a cause of pneumonia in the immunocompromised host, more often in stem cell transplant patients and those with hematologic malignancy. Influenza is involved in one-third of such cases. Respiratory syncytial virus and parainfluenza are also commonly involved. With the advent of rapidly available viral PCR testing, human 


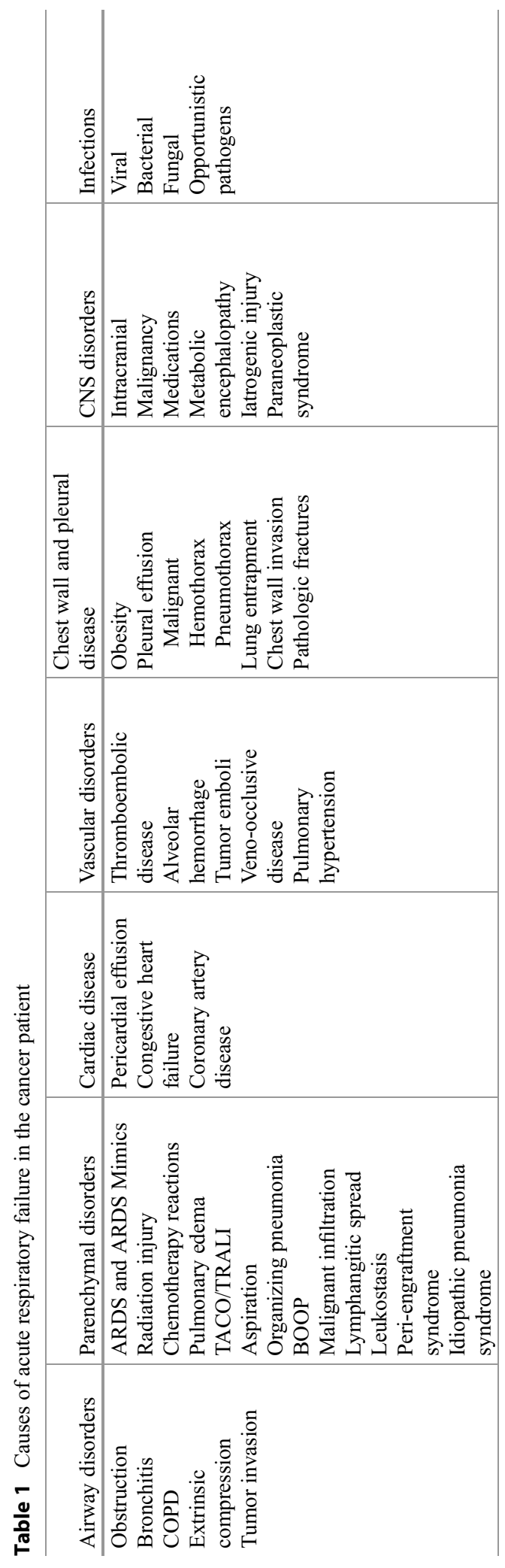


metapneumovirus has emerged as a common respiratory viral pathogen [154]. Immunocompromised oncology patients may present as symptoms of upper respiratory illness such as laryngitis, rhinorrhea, and congestion. In contrast to their immunocompetent counterparts, cancer patients may not rapidly improve over 3-5 days; rather they may progress to severe lower respiratory infection and manifest cough, wheezing, and hypoxia [88].

\section{Opportunistic Infections}

Opportunistic infections are common in these patients and may account for up to $30 \%$ of pulmonary infections [153]. Such infections include cytomegalovirus (CMV) pneumonia, invasive pulmonary aspergillosis, Pneumocystis jirovecii, tuberculosis, and atypical mycobacteria.

\section{Pneumonia}

Largely characterized as an opportunistic infection, the incidence of CMV pneumonia in patients with hematologic malignancy is estimated near $40 \%$ of seropositive patients [110]. At least $60 \%$ of the US population has been exposed to CMV [189]. In patients with hematologic malignancy, steroid therapy, or bone marrow transplantation, latent CMV may reactivate and affect nearly any organ. Life threatening pneumonia may develop in this group. The radiographic presentation is variable and nonspecific including lobar consolidation mimicking bacterial processes, groundglass opacities, or reticulonodular infiltrates. Serum CMV DNA polymerase chain reaction (PCR) has a high sensitivity but a low positive predictive value; thus, the diagnosis relies on culture or histopathology [63]. True infection warrants treatment with ganciclovir or foscarnet. Interestingly, increased incidence of co-infection with Nocardia and molds such as Aspergillus has been documented in patients with CMV pneumonia [44]. It is unclear if this is an epiphenomenon or what the mechanism is for such co-infection.

\section{Pulmonary Aspergillosis}

Invasive aspergillus is a major cause of death in patients following BMT. It commonly involves the lungs and sinuses of neutropenic patients and may present with fever, chest pain, and hemoptysis. Often, fever may be the only manifestation and the disease is suspected via lung imaging with CT scan. Specific patterns suggestive of various types of pulmonary aspergillosis are described in Table 2. Prompt diagnosis is imperative as the angioinvasive fungus may disseminate outside the respiratory tract to other organs. Such dissemination portends a mortality rate between $40 \%$ and $80 \%$ [20, 112]. Voriconazole is the drug of choice; however, combination therapy may be required.

\section{Pneumocystis jirovecii Pneumonia}

Infection with the opportunistic fungi Pneumocystis jirovecii is most common in individuals with T-cell deficiency. Classically described in patients with HIV/AIDS, this infection is also common and increasingly seen in those with hematologic malignancy or bone marrow transplant, as well as in those taking moderate doses of systemic corticosteroids. A Mayo Clinic series of 116 patients with PJP evaluated the epidemiology of the infection and noted hematologic malignancy as a risk factor in $30 \%$ of cases. Patients with solid tumors comprised $13 \%$ of infections [187]. Symptoms are often more severe in the non-HIV patient. Respiratory failure is common. Classic radiographic findings are listed in Table 2.

\section{Nocardia}

Often overlooked in the immunocompromised host is pulmonary infection with unusual pathogens such as Nocardia. Nocardia is a grampositive infection in which two-thirds of patients demonstrate impaired cell medicated defense. Such deficiency is seen in lymphoma, bone marrow transplant, and with glucocorticoid use [178]. An inoculum is inhaled which leads to Nocardia pneumonia, the most common pulmonary manifestation. Pleural involvement and 
Table 2 Computed tomography characteristics of select causes of acute respiratory failure in cancer patients

\begin{tabular}{l|l}
\hline Disease & Radiographic correlates \\
\hline ARDS & $\begin{array}{l}\text { Diffuse, bilateral, and symmetric opacities which become more uniform in dependent } \\
\text { areas. Often interlobular septal thickening and ground glass attenuation (crazy paving } \\
\text { pattern) is present [79] }\end{array}$ \\
\hline $\begin{array}{l}\text { Acute interstitial } \\
\text { pneumonia }\end{array}$ & $\begin{array}{l}\text { Diffuse, bilateral, and symmetric ground glass opacities and parenchymal consolidation } \\
\text { which may be most apparent in peripheral and lower lung regions. Later fibrotic phases } \\
\text { may manifest with traction bronchiectasis and honeycombing [3] }\end{array}$ \\
\hline Organizing pneumonia & $\begin{array}{l}\text { Patchy areas of opacification which may be peripheral, subpleural or peribronchial. } \\
\text { Centrilobular nodules may be present. Ground glass opacities may be surrounded by a } \\
\text { rim of consolidation (Atoll or "reverse halo" sign) [70] }\end{array}$ \\
\hline $\begin{array}{l}\text { Diffuse alveolar } \\
\text { hemorrhage }\end{array}$ & $\begin{array}{l}\text { Ground glass attenuation with bilateral (often hilar) consolidation in a "butterfly" } \\
\text { appearance. Typically spares the subpleural areas [140] }\end{array}$ \\
\hline Lymphangitic spread of & $\begin{array}{l}\text { Interlobular septal thickening which is nodular. Perilymphatic nodules present. Lung } \\
\text { architecture is generally preserved. Mediastinal adenopathy may be present [93] }\end{array}$ \\
\hline PJP pneumonia & $\begin{array}{l}\text { Bilateral perihilar and central ground glass opacities often associated with smooth } \\
\text { interlobular septal thickening (crazy paving pattern). Cysts may be found within the } \\
\text { ground glass opacities. Cysts may have bizarre shapes [125] }\end{array}$ \\
\hline Pulmonary aspergillosis & $\begin{array}{l}\text { 1. Angioinvasive disease: pulmonary nodules with a halo of ground glass surrounding the } \\
\text { nodule (Halo sign). Ground glass represents hemorrhage. Wedge shaped infarct may be } \\
\text { present. Necrosis and cavitation may occur } \\
\text { 2. Allergic bronchopulmonary aspergillus: central or upper lobe bronchiectasis with } \\
\text { mucoid impaction, often of high attenuation. Mucoid impaction may results in } \\
\text { bronchocoele (finger-in-glove sign) } \\
\text { 3. Aspergilloma: Thin or thick-walled cavity with soft tissue density within. Mass may be } \\
\text { mobile with positioning [73] }\end{array}$ \\
\hline
\end{tabular}

emphysema is common; as is disseminated CNS disease. Diagnosis if frequently delayed and is often radiographically confused with metastatic cancer [113].

\section{Fungal Pneumonia}

A useful way to categorize fungal pneumonia is based on the patient's pattern of immunodeficiency. For example, neutropenia predisposes to infection with angioinvasive molds such as Mucor and Aspergillus. On the other hand, patients with T-cell defects are subject to infections with Cryptococcus, PJP, and endemic mycosis such as Coccidioides immitis, Blastomyces dermatitidis, and Histoplasma capsulatum.

Isolated cryptococcal pneumonia is uncommon and pulmonary infection generally indicates widespread dissemination. In a review of 34 HIV-negative immunocompromised patients with cryptococcal pneumonia, 28 had evidence of extrapulmonary disease at time of diagnosis [98]. The clinical course may be quiescent with prolonged indolent infection, or the patient may present with fulminant respiratory failure and ARDS [132, 180]. CNS involvement should be sought out in all patients with pulmonary Cryptococcus. Mild cases may be treated with azole therapy, whereas severe respiratory failure and disseminated disease necessitate amphotericin B.

\section{Noninfectious Parenchymal Disorders}

\section{ARDS and ARDS Mimics}

The acute respiratory distress syndrome imparts a high mortality and is characterized by infiltration of the alveoli by protein-rich pulmonary edema with resultant severe mixed respiratory failure. Clinically it is defined as acute onset of respiratory symptoms within 1 week, bilateral radiographic airspace opacities, hypoxemia defined as arterial partial pressure of oxygen to fraction of inspired oxygen ratio less than $300 \mathrm{mmHg}$ on at least $5 \mathrm{cmH}_{2} \mathrm{O}$ of PEEP, and exclusion of cardiogenic 
cause of the alveolar edema $[9,10]$. Numerous conditions predispose to the syndrome, many of which are commonly found in the oncology patient. Sepsis, aspiration, massive transfusion and transfusion reactions, drugs, and even hematopoetic stem cell transplantation are associated with ARDS [99, 102, 136].

There is a selection of diffuse lung diseases that mimic ARDS both clinically and radiographically but have different etiologic and pathophysiologic characteristics. It is important to distinguish these from true ARDS as they typically respond well to systemic glucocorticoid therapy. These entities include: acute interstitial pneumonia (AIP), acute eosinophilic pneumonia, organizing pneumonia, diffuse alveolar hemorrhage, and acute hypersensitivity pneumonitis. Confusion is commonplace as malignancy, chemotherapy regimens, and bone marrow transplantation may predispose to either ARDS or respiratory failure from an ARDS mimic $[4,128,163]$. In practice, one often cannot distinguish between them without aid of bronchoscopy or surgical lung biopsy. Differentiation between true ARDS versus ARDS imitators is important as ARDS mimics may be more responsive to anti-inflammatory therapies.

\section{Radiation Injury and Fibrosis}

Radiation therapy (RT) is a mainstay of therapy for various stages of lung, neck, and breast cancer as well as lymphoma. The use of RT has increased, in part as it is tolerated well, generally with few side effects. The lung is radiosensitive and toxicity may occur as collateral damage with an incidence of up to $28 \%$. The incidence is less frequent when radiation is used for treatment of breast cancer [115]. Clinically, the lung has two distinct pathologic responses to ionizing radiation. Radiation pneumonitis is an acute or subacute reaction which occurs within 6 months of thoracic radiotherapy. Risk for acute radiation pneumonitis depends on concomitant use of certain chemotherapy agents, prior radiation, total dose and field size, as well as host factors such as prior chronic lung disease [52]. Dyspnea, cough, and fever develop prior to radiographic changes. Pulmonary function tests demonstrate restrictive ventilatory defect. Reduction in the diffusion capacity (DLCO) is the most sensitive maker of acute and subacute radiation injury [126]. Depending on the degree of lung tissue damaged, the course may be self-limited or progress to severe acute lung injury and fulminant hypoxic respiratory failure [82]. CT correlation can be used to assess the severity of disease. Oxygen and concomitant chemotherapy may worsen the lung injury [168]. The areas of RP tend to develop fibrosis over time [49]. Corticosteroids remain the mainstay of treatment.

Radiation fibrosis occurs 6 months to 1 year following completion of radiation therapy. The development of acute radiation pneumonitis is not a prerequisite for progression to fibrosis; patients may be asymptomatic until the late onset of breathlessness or in severe cases, respiratory failure and acute cor pulmonale. The diaphragm may also be affected resulting in hypoventilation [126]. Fibrosis tends to occur on the margins of the radiation field. Fibrosis may cause distortion of the interstitium or traction of the airways. Fibrosis may alter the function of the mucociliary elevator and predispose patients to infection [126]. Treatment is largely supportive and steroids have no role in therapy of radiation fibrosis. Radiation therapy may also lead to radiationassociated organizing pneumonia.

\section{Drug-Induced Lung Injury}

Pulmonary drug toxicity is a diagnosis of exclusion and can be difficult to diagnose owing to protean clinical and radiographic manifestations [147]. The presentation is often subacute or chronic and insidious as opposed to acute. It is estimated that up to $20 \%$ of patients treated with cytotoxic drugs may develop respiratory symptoms [158]. Numerous drugs are associated with various forms of pulmonary toxicity and the diagnosis should be considered in any cancer patient with new respiratory failure and pulmonary opacities on chest imaging. Drug-induced damage may be dose dependent or idiosyncratic [131]. Databases such as Pneumotox (https://www. 
Table 3 Pulmonary complications associated with common chemotherapeutic drugs. (Disease patterns referenced from Pneumotox)

\begin{tabular}{|c|c|}
\hline Drug & Associated pulmonary complication \\
\hline Bleomycin & $\begin{array}{l}\text { ARDS, eosinophilic pneumonia, organizing pneumonia, pulmonary fibrosis, acute interstitial } \\
\text { pneumonia, pneumothorax, pulmonary veno-occlusive disease, NSIP }\end{array}$ \\
\hline 5-FU & Pulmonary fibrosis, ARDS, pulmonary edema \\
\hline Bevacizumab & ARDS, DAH, bronchospasm, pulmonary arterial hypertension \\
\hline Bortezomib & Organizing pneumonia, ARDS, DAH, pulmonary arterial hypertension, infection \\
\hline Carfilzomib & DAH, pulmonary arterial hypertension \\
\hline Carmustine & $\begin{array}{l}\text { Pulmonary fibrosis, ARDS, pleural effusion, pneumothorax, radiation recall pneumonitis, } \\
\text { pleuroparenchymal fibroelastosis (PPFE) }\end{array}$ \\
\hline Cyclophosphamide & $\begin{array}{l}\text { Organizing pneumonia, pulmonary fibrosis, PPFE, ARDS, DAH, bronchospasm, pleural } \\
\text { effusion, pulmonary veno-occlusive disease }\end{array}$ \\
\hline Doxorubicin & Organizing pneumonia, pulmonary fibrosis, ARDS, radiation recall pneumonitis \\
\hline Etoposide & ARDS, DAH, bronchospasm, angioedema \\
\hline Fludarabine & $\begin{array}{l}\text { Eosinophilic pneumonia (acute and chronic), organizing pneumonia, lung nodues, ARDS, DAH, } \\
\text { pleuritic }\end{array}$ \\
\hline Gemcitabine & $\begin{array}{l}\text { Eosinophilic pneumonia, pulmonary fibrosis, radiation recall pneumonitis, AIP or ARDS, } \\
\text { pulmonary edema, bronchospasm, pleural effusion, pleuritis }\end{array}$ \\
\hline Ifosfamide & Pulmonary fibrosis, radiation recall pneumonitis, pulmonary edema, hypoxia \\
\hline Melphalan & Pulmonary fibrosis, ARDS, bronchospasm, organizing pneumonia, NSIP, UIP \\
\hline Methotrexate & $\begin{array}{l}\text { Organizing pneumonia, pulmonary fibrosis, lung nodules, ARDS, AIP, DAH, bronchospasm, } \\
\text { eosinophilic pleural effusion, pulmonary embolism, angioedema }\end{array}$ \\
\hline Paclitaxel & ARDS and AIP, radiation recall pneumonitis \\
\hline Pemetrexed & Organizing pneumonia, ARDS and AIP, DAH, pleuritis, capillary leak \\
\hline Rituximab & $\begin{array}{l}\text { Organizing pneumonia, pulmonary fibrosis, ARDS, pulmonary edema, hemoptysis, cough, } \\
\text { asthma attack }\end{array}$ \\
\hline Thalidomide & $\begin{array}{l}\text { Eosinophilic pneumonia, organizing pneumonia, pulmonary embolism, pulmonary arterial } \\
\text { hypertension }\end{array}$ \\
\hline Vincristine & Cellular NSIP, laryngospasm \\
\hline Nivolumab & Eosinophilic pneumonia, AIP, organizing pneumonia, shrinking lung, ARDS, pleural effusion \\
\hline
\end{tabular}

pneumotox.com/drug/index/) have been established detailing the many histopathologic and radiologic findings associated with numerous agents. These resources are invaluable in formulating a differential diagnosis and it is often useful to correlate a specific radiographic pattern to a drug in question. In terms of pathophysiological mechanism, bleomycin toxicity is well understood and serves as an archetype for our understanding of drug-induced pulmonary toxicity. Bleomycin damages capillary endothelium and type I pneumocytes leading to free radical damage and exaggerated inflammatory response. Given the release of free radicals, oxygen therapy may worsen the lung injury. This is an unfortunate paradox as the very supportive care used in hypoxemia may be detrimental [46, 168, 171]. The clinical and/or radiographic pattern is variable and not specific to any drug. Common features include: organizing pneumonia, eosinophilic pneumonia, cardiac and noncardiac pulmonary edema, bronchoconstriction, diffuse alveolar hemorrhage, radiation recall, and more $[92,148,150]$. Table 3 lists radiographic manifestations of select commonly used antineoplastic drugs.

Newer antineoplastic agents now in circulation are also associated with various forms of pulmonary toxicity. These immunomodulating monoclonal antibody therapies targeting anticytotoxic T-lymphocyte antigen 4 (CTLA-4) and programed death 1 (PD-1) are being commonly used in nonsmall cell carcinoma as well as against melanoma. They have been associated with generalized dyspnea, pneumonitis, and even organizing pneumonia. Depending on the degree of severity, treatment may entail simply withdrawing the offending agent, or in severe cases, high dose glucocorticoids [22, 129]. 
CAR-T therapy is associated with cytokine release syndrome, which affects multiple organs, including the lungs. Pulmonary side effects of this emerging therapy include pulmonary edema, pneumonitis, and subsequent respiratory failure, often severe enough to require mechanical ventilation [38].

\section{Aspiration Pneumonitis and Pneumonia}

Patients with head and neck cancer, gastrointestinal malignancy, or those who have undergone CNS or mediastinal radiation therapy are at risk for aspiration pneumonia. The use of opioid narcotics and sedatives further increases this risk. Only $20 \%$ of frank aspiration events result in clinical infection [111]. The majority of aspiration imparts a chemical pneumonitis. Yet the incidence of frank aspiration events is likely underreported, especially in the intensive care unit. Based on pepsin measurements in BAL, a multicenter study of 360 mechanically ventilated patients estimated that $89 \%$ of patients undergoing mechanical ventilation silently aspirate [118]. This is particularly detrimental in the cancer population with waning immune response and may lead to further catastrophic complications such as ARDS.

\section{Transfusion-Related Acute Lung Injury and Circulatory Overload (TRALI/TACO)}

Transfusion-related acute lung injury (TRALI) is an immune mediated inflammatory noncardiogenic pulmonary edema that occurs following transfusion of blood products, most frequently plasma [179]. It most often manifests within minutes to hours. Clinically it is defined as new hypoxia and diffuse bilateral infiltrates that occur within $6 \mathrm{~h}$ of transfusion $[33,156]$. Fever is common as is hypotension. Oncology patients are especially at risk given their frequent need for transfusion. This diagnosis should be considered with any new respiratory failure following transfusion, even of allogenic stem cells. TRALI may be confused with transfusion related circulatory overload (TACO), though latter is more often associated with cardiac dysfunction, need for rapid infusion of fluids, and an overall positive fluid balance [51].

\section{Organizing Pneumonia}

Organizing pneumonia, often referred to as bronchiolitis obliterans organizing pneumonia or cryptogenic organizing pneumonia, is one of the idiopathic interstitial pneumonitis characterized by proliferation of granulation tissue with the alveoli and alveolar ducts [54]. Clinically its manifestations are nonspecific and often overlap with infectious pneumonia. When no precipitating cause can be identified, it is referred to as cryptogenic organizing pneumonia [56]. Characteristic radiographic findings are included in Table 2. There are many inciting causes including infection, autoimmune disease, vasculitis, immune deficiencies, and transplantation [43]. It has been reported after engraftment of in bone marrow recipients and is associated with acute and chronic graft versus host disease [4]. It may also occur in the context of lung cancer or hematologic malignancy including acute and chronic leukemias, myelodysplastic syndrome, t-cell leukemia, Evans syndrome, and Hodgkin disease [167]. It may also occur as a response to acute drug toxicity or even following radiation therapy [121, 170]. Diagnosis established definitively by lung or transbronchial biopsy but may be suggested on bronchoalveolar lavage. It is a particularly satisfying diagnosis to make as it demonstrates remarkable response to corticosteroid treatment. Relapses, however, are common following withdrawal of steroids [104].

\section{Parenchymal Disorders Common to HCT Patients}

Pulmonary complications of HCT are common as transplant conditioning and posttransplant immunosuppression predispose to numerous infections and noninfectious cause of respiratory failure. Whereas some conditions occur in other cancer patients (organizing pneumonia, drug toxicity, 
infection, pulmonary edema, and diffuse alveolar hemorrhage and more), others are specific to the HCT patient. Such disease states include the engraftment syndrome and idiopathic pneumonia syndrome.

\section{Peri-Engraftment Respiratory Distress Syndrome (PERDS)}

Over $10 \%$ of patients undergoing HCT will develop PERDS. It presents during neutrophil recovery and is characterized by fever, rash, and hypoxia from noncardiogenic pulmonary edema. Respiratory failure requiring mechanical ventilation is common [2, 47]. The Spitzer criteria are used for diagnosis. Major criteria include fever, rash, and pulmonary edema. Minor criteria are weight gain, hepatic or renal injury, and encephalopathy. Diagnosis is established by incorporation of three major, or two major and one minor criteria [55].

\section{Idiopathic Pneumonia Syndrome}

The idiopathic pneumonia syndrome is a complication of allogenic stem cell transplant that may occur between weeks to months of transplantation. It has been defined as radiographic diffuse alveolar infiltrates with symptoms of pneumonia and objective hypoxia. To fulfil the criteria, infection must be ruled out by negative bronchoalveolar lavage or biopsy [48]. Disease progression is rapid and often requires mechanical ventilation. Tumor Necrosis Factor alpha inhibitors such as etanercept or corticosteroids may be of some benefit [47].

\section{Diffuse Alveolar Hemorrhage (DAH)}

Hemorrhage into the alveolar space with or without clinical hemoptysis defines DAH. Bleeding may be bland, or be due to pulmonary capillaritis or diffuse alveolar damage. Many disease states are associated with DAH, but in the cancer patient, DAH is most often linked to chemotherapy and HCT. Risk factors include advancing age, intensive ablative regimens, concomitant infection, and GVHD. Diagnosis is based on BAL with return of progressively bloodier aliquots of fluid, or by demonstration of $>20 \%$ hemosiderin laden macrophages [47].

\section{Vascular Disorders}

\section{Pulmonary Embolism}

Clinically significant deep venous thrombosis and pulmonary embolism may occur in $10 \%$ of patients with cancer as a result of a hypercoagulable state, tumor compression of blood vessels, and due to surgery and some chemotherapy agents [84, 175]. Risk also increases with advanced stage of cancer and tumor type. Of the solid tumors, brain, pancreatic, and stomach cancers are most associated with thromboembolic disease. Of the hematologic malignancies, AML is the most frequent culprit of thrombosis [186]. Most pulmonary emboli originate in the proximal veins of the lower extremities. Pulmonary embolism may be classified as acute or chronic, by size, or by hemodynamic characteristics $[95,96]$. Low molecular weight heparin is the agent of choice for treatment $[96,105]$. In cases of massive pulmonary embolism with hemodynamic compromise, the American College of Chest Physicians suggests use of thrombolytics or catheter directed thrombolysis (Grade 2B and 2C recommendations) [96]. Use of thrombolytics is contraindicated in the stable patient [96], though there is much debate if hemodynamically stable patients with high risk of deterioration (submassive PE) benefit from clot lysis [119]. Often patients with malignancy have contraindications to anticoagulation. These patients may benefit from placement of a filter within the inferior vena cava. However, recent evidence notes that in patients that can receive anticoagulation, the concomitant use of such filters may not prevent recurrence of pulmonary embolism [120].

\section{Pulmonary Leukostasis}

Pulmonary leukostasis occurs in patients with acute leukemia or chronic myeloid leukemia in blast crisis and is a result of symptomatic hyperleukocystosis [60, 62]. White blood cells are typically in excess of 50,000-100,000 per microliter of blood which greatly increases blood viscosity. In addition to cellular occlusion of the microvasculature, metabolic activity of neutrophils results in hypoxemia and leads to cascade of cytokines and subsequent pulmonary injury [107]. Chest 
radiograph may or may not reveal infiltrates. Partial pressure of oxygen in an arterial blood gas may be spuriously low due to local metabolic activity of neutrophils. As such, pulse oximetry more accurately reflects oxygen balance in these patients. Prompt treatment with leukopheresis is necessary as left unchecked, mortality rates may exceed $40 \%$ [62].

\section{Cardiac Causes of Acute Respiratory Failure}

\section{Congestive Heart Failure}

Chemotherapy-induced cardiomyopathy may not become apparent until the development of a high-output challenge such as anemia or infection. Often it is discovered during fluid resuscitation or with subsequent chemotherapy [168]. Offending agents include anthracyclines, cyclophosphamide, and more. Monoclonal antibodies such as Trastuzumab are also associated with cardiac dysfunction [34]. Chemotherapy-induced heart failure may manifest as acute pulmonary edema and subsequent acute respiratory failure.

\section{Pulmonary-Veno Occlusive Disease}

A particularly insidious cause of respiratory failure in the cancer patient (albeit rare) is pulmonary-veno occlusive disease. A unique form of postcapillary pulmonary hypertension, this disorder is rapidly fatal without lung transplant. Various chemotherapy regimens are associated with the development of this disorder including bleomycin and mitomycin. Bone marrow transplantation is also a risk factor $[66,77]$.

\section{Other Causes of Acute Respiratory Failure}

\section{Pleural Effusions}

Symptomatic pleural effusions may compress the lung with resultant ARF. These effusions represent sequela of a number of conditions common to the cancer patient including primary malignant effusion, infectious parapneumonic effusion and empyema, pulmonary embolism, heart failure, and more. Any new symptomatic effusion, especially in the context of infection, demands timely sampling [144]. Malignant pleural effusion typically represents an advanced stage of cancer and may be due to metastatic disease, lymphoma, or primary pleural malignancy such as mesothelioma. Treatment will be dictated by the underlying etiology. Depending on the rate of accumulation, malignant effusions may be dealt with by serial thoracentesis, indwelling pleural catheters, or pleurodesis [85].

\section{Diagnosis}

Respiratory failure is life threatening, and prompt diagnosis of the initiating cause may improve prognosis $[14,87]$. The approach taken depends in part on the patient's clinical condition.

Subacute and chronic respiratory failure may afford more time to gather diagnostic data, whereas severe acute hypoxemia or impending cardiopulmonary collapse warrants empiric therapeutic action in concert with rapid diagnostic precision.

The history and pace of cardiopulmonary deterioration provide vital clues to the underlying etiology. Consideration of the nature of immunologic defect is paramount, as is adjunctive chemotherapy and radiation therapy, travel history, environmental exposures, recent hospitalizations, and procedures. A detailed review of prior chemotherapy regimens, past and current medications (prescription and over the counter) is obligatory. Careful attention to subtle clinical signs may reveal a diagnosis. Following a detailed history and physical examination, laboratory and radiographic investigations should selectively pursued to confirm or reject hypothesized differential diagnosis in a Bayesian approach.

Azoulay and colleagues outlined a diagnostic approach to ARF in cancer patients [12]. The utility of this strategy was found clinically useful in an original investigation published in the European Respiratory Journal [153]. This approach, easily remembered by the mnemonic DIRECT, is outlined in Table 4. 
Table 4 DIRECT criteria for identifying causes of acute respiratory failure in cancer patients. (Adapted from Ref. [12])

\section{DIRECT}

Delay since malignancy onset or HSCT, since symptom onset and since implementation of antibiotics/prophylaxis

Nature of immune deficiency

Radiographic appearance

Experience and knowledge of the literature

Clinical picture

Findings by HRCT

\section{Diagnostic Studies}

Historically, flexible bronchoscopy with bronchoalveolar lavage and biopsy has been the diagnostic modality of choice. Yet this procedure yields a diagnosis in approximately $50 \%$ of patients [39, 40, 114, 138, 177]. Some studies quote a higher diagnostic yield of nearly $90 \%$ in the bone marrow transplant population [165]. More recent data suggest that bronchoscopy changes the course of management in only $18 \%$ of cases [15]. The procedure is not without risk although the complication rates of bronchoscopy are generally low and occur in less than $1 \%$ of patients. However, in the hypoxemic cancer patient, the risk of complications increases tenfold. Open lung biopsy or video-assisted thoracoscopic surgery may provide a specific diagnosis more frequently than bronchoscopy. Yet the complication rates may be even higher with a surgical approach. Often the critically ill cancer patient is of poor protoplasm for undergoing surgery with general anesthesia [168]. In essence, the moderate diagnostic yield of bronchoscopy (or surgery) must be weighed against the risk of complications. The primary concern is worsening hypoxemia to the degree requiring invasive mechanical ventilation. This complication is a near death sentence as mechanical ventilation in those with hematologic malignancy portends a mortality rate ranging from $44 \%$ to $100 \%$ [14]. Those with solid malignancy have improved outcomes undergoing mechanical ventilation compared to patients with hematologic disease. Given this risk, multiple simultaneous noninvasive modalities (echocardiography, computed tomography, etc.) should be considered prior to bronchoscopy. Noninvasive testing without bronchoscopy is noninferior to FO-BAL in identifying a cause of ARF in patients with cancer and may in fact identify the cause of ARF more quickly than FO-BAL [15].

Noninvasive testing such as bedside ultrasound and echocardiography is rapidly obtained and provides a wealth of information. Acute cardiogenic pulmonary edema is present in $10 \%$ of cancer patients with ARF. Given the wide prevalence of coronary artery disease and the use of cardiotoxic agents such as anthracyclines, pericardial effusions and cardiogenic pulmonary edema should be ruled out in all cancer patients with acute respiratory failure. History, exam, and review of medications may increase suspicion for acute heart failure. Interestingly, plasma brain natriuretic peptide may be spuriously elevated in patients with malignancy (sources). Therefore, caution is warranted in the use of BNP in cancer patients. Echocardiography is the diagnostic modality of choice to suggest the presence of cardiac dysfunction. Bedside ultrasound may reveal evidence of extra-vascular lung water or pleural effusions [137].

Infection leading to respiratory failure should be of chief concern. When suspecting infection, time course of the cancer patient's fundamental illness should be kept in mind, as should nature of the patient's immunosuppression. There has been an influx of biochemical assays that may reveal a culprit infection without the need for invasive diagnostics such as bronchoscopy or surgical lung biopsy. Nasopharyngeal viral PCR, immunofluorescence testing, and serum and urine antigen testing may provide valuable diagnostic data. Classic blood and sputum testing is a blunt instrument, yet exciting new tests are currently available, albeit costly. The Karius Digital Culture ${ }^{\mathrm{TM}}$ is a clinically validated test that can rapidly detect more than 1,250 bacteria, viruses, fungi, and parasites from a single blood draw. It has been demonstrated to have high diagnostic yield of fastidiously difficult to culture pathogens, as well in those patients who have already received broad spectrum antibiotics. A pilot study revealed probable infectious culprits (including 
Aspergillus fumigatus) in 18 patients with neutropenic fever, even in patients with no definitively positive blood cultures (need to add the source). This testing modality seems promising, but more research is needed before becoming mainstream, especially at the cost of 2,000 USD.

The radiographic pattern of illness is invaluable in the assessment of the hypoxemic cancer patient. However, keep in mind that the plain chest radiograph lacks sensitivity in this population due to muted inflammatory responses. In patients with febrile neutropenia, the plain chest radiograph has a sensitivity of only $36 \%$ when evaluating for suspected infection [78]. The sensitivity and specificity of thoracic computed tomography is greater in the evaluation of suspected infection. In addition it also provides detailed patterns such as nodules, infiltrates and consolidation, cysts, cavitation, and more, which can guide physicians in establishing a differential diagnosis and in planning invasive diagnostic procedures. For example, with the appropriate history of a patient with Hodgkin's disease or a patient on corticosteroids, a diffuse bilateral process with hilar ground glass opacities and interlobular septal thickening (crazy-paving) with cysts of varying size should be considered infection with Pneumocystis jirovecii pneumonia until proven otherwise. Often CT may itself be diagnostic. CT pulmonary angiography is now the gold standard for the diagnosis of acute pulmonary embolism [91]. Table 2 lists the radiographic characteristics of select causes of acute and chronic respiratory failure in patients with malignancy.

Simplicity is not the norm in the immunocompromised host and the principle of "Occam's razor" may not apply to this population. Often multiple simultaneous infections or conditions may coexist. Thus, a broad and thorough evaluation is warranted in any cancer patient with acute or chronic respiratory failure.

\section{Management}

Optimal care for the critical ill cancer patient with ARF requires not only a solid foundation in the principles of cardiopulmonary physiology and appropriate support, but also of the fundamental neoplastic disease-related and treatment-related complications that can occur in the cancer population. Staying abreast of the rapid development of novel chemotherapeutics and advances in ICU care is becoming increasingly difficult. Given this, and the complexity of the critically ill cancer patient, these patients should be cared for by a multidisciplinary team with expertise in pulmonary and critical care, oncology, and palliative care. Such combined efforts have been documented to improve patient outcomes in the ICU setting [141]. In addition, the collective experience of multiple specialists can hasten the diagnosis in the cancer patient with ARF. Given that the differential diagnosis for hypoxemia in the cancer patient is so large, it is important to approach the diagnosis through the lens of multiple looking glasses.

Although there are many causes of respiratory failure in those with malignancy, treatment principles are similar. Supportive care directed at the underlying root cause of a cancer patient's respiratory deterioration remains the goal of critical care admission. Treatment of type I respiratory failure should include oxygen therapy, whereas ventilatory support should be utilized in patients with hypercapnia. Often overlap of hypoxemia and hypercanpea may occur, further complicating therapy. The cause of ARF should be established as this has important prognostic and therapeutic implications. For example, the ventilatory strategy employed for the patient with head and neck cancer suffering from upper airway obstruction may differ from the method used to support a patient with hypoxiemia from cardiogenic pulmonary edema. Likewise the tenets of treatment for a patient with diffuse lung disease and refractory hypoxemia will differ drastically compared to the therapy required for a patient with NSCLC and COPD exacerbation. Whatever the reason for respiratory failure in the cancer patient, establishing an airway, invasively or noninvasively takes precedence as in any other respiratory crisis. Figure 1 outlines an approach to supportive care for respiratory failure in the oncology patient. 


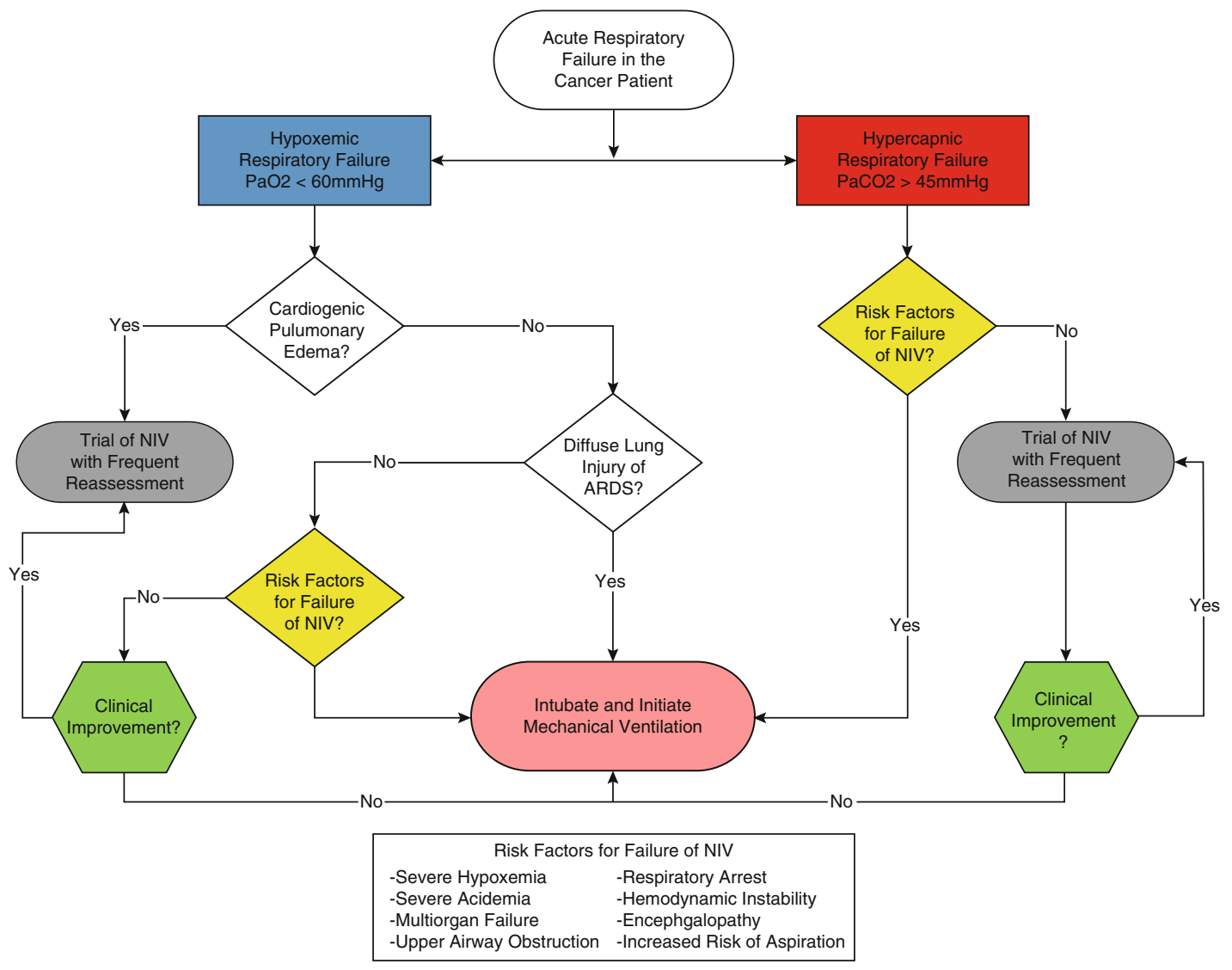

Fig. 1 Initial supportive treatment for respiratory failure in the cancer patient

\section{Noninvasive Positive Pressure Ventilation and High-Flow Nasal Oxygenation}

Twenty years ago, mechanical ventilation portended a near death sentence for the hematology and bone marrow transplant patient. With an already weakened immune system, these patients fell victim to virulent nosocomial infections and ventilator associated pneumonia [58]. The endotracheal cuff may also erode the trachea mucosa allowing the pooled nidus of bacteria infested secretions of the upper airway to translocate to the blood stream or migrate to the lower respiratory tract [57]. Tracheal erosions also predispose to bleeding in the pancytopenic patient.

Given this, interest in treating hypoxic respiratory failure in this population with noninvasive modalities blossomed. In 2000, Antonelli et al. evaluated the use of NIV in postoperative solid organ transplant recipients. While cancer patients were not included, use of NIV in these immunocompromised patients following transplantation improved $\mathrm{PaO}_{2}$ and reduced the rate of fatal complications. In addition, those treated with NIV less often required escalation to mechanical ventilation [8]. The following year, a single center, randomized controlled trail of 52 immunocompromised hypoxemic patients demonstrated that noninvasive positive pressure ventilation delivered by face mask reduced mortality and reduced complications when compared to oxygen therapy alone [89]. The population in this study was overwhelmingly comprised of patients with hematologic cancers. This study noted a $93 \%$ case mortality rate in those patients treated with oxygen alone. Over the subsequent decade, survival of cancer patients in the ICU improved, even 
among those undergoing mechanical ventilation. Along with this trend, fewer studies demonstrated benefit of NIV in hematology patients. Often the etiology of respiratory failure was not taken into account, nor was time on onset of ARF to trial of noninvasive ventilation controlled. Patients with cardiogenic pulmonary edema and hypercapnic respiratory failure were included, the presence of which may have further confounded the ability to parse out which patients truly benefited from an early trial of NIV [64].

In 2012 Wermke conducted a study evaluating early use of NIV in patients with hypoxic respiratory following allogenic hematopoietic stem cell transplant. Eighty-six patients with homogenous baseline characteristics were enrolled and randomized to oxygen therapy only versus treatment with NIV. This population of patients was studied within the wards rather than intensive care unit. There was no mortality difference between the two groups, nor was there a difference in escalation to ICU level care or implementation of invasive mechanical ventilation [184]. Studies in patients without cancer presenting with hypoxic respiratory failure due to community acquired pneumonia and without associated organ dysfunction have shown benefit with the use of NIV $[36,72,97]$. This is not borne out in the cancer patient. In fact, data indicate that cancer patients with documented respiratory infection may do worse when subjected to NIV as first line therapy for hypoxemia [71].

Presumably the same variables that plague outcomes of NIV in the noncancer patient with hypoxic respiratory failure also affect the outcomes in the cancer population. Hypoxic respiratory failure de novo is often prolonged and not immediately reversible. In contrast to hypercapnic respiratory failure or type I respiratory failure from cardiogenic pulmonary edema, NIV without substantial inspiratory support does not reduce the work of breathing in most cases of hypoxia [103]. The inspiratory demand is increased in settings of hypoxia. This flow demand imparts more diaphragmatic inspiratory effort, ergo vast reductions in intrapleural pressure. Combining large negative pleural pressure with increased inspiratory pressures produces enormous swings in transpulmonary pressure and tidal volumes which may worsen diffuse lung injury [94]. In addition, many causes of type I respiratory failure are anatomically heterogeneous resulting in over distention of smaller, healthier sections of lung. Respiratory compliance is associated with the volume of this remaining functional lung. Recent data from a post hoc observational analysis of nine randomized trials have associated driving pressure (tidal volume divided by respiratory system compliance) as a surrogate marker of "adjusted lung size." In this study, the relative risk of death increased in a near linear fashion with increasing driving pressures, even when tidal volume is kept within a "lung protective" window of $6 \mathrm{ml} / \mathrm{kg}$ ideal body weight [7]. Higher driving pressures in NIV are associated with patient intolerance, leak around the mask, as well as gastric over distention with possible aspiration [103].

Specialized high-Flow nasal cannula (HFNC) is capable of delivering warmed and humidified oxygen at flow between 30 and $60 \mathrm{l} / \mathrm{min}$ and may circumvent some of the adverse physiology of NIV in hypoxemia. HFNC is also associated with improved patient tolerance, a modest degree of positive end-expiratory pressure, and reduced volume of dead space ventilation [23]. Benefits in patients with cancer have been demonstrated in the palliative arena $[67,83,106]$. Yet the place of this modality of support is not firmly established. A randomized controlled trial reported survival benefit in type I respiratory failure when HFNC was used in lieu NIV or standard oxygen therapy [74]. This was not borne out in a 2017 study specifically examining the use of HFNC in patients with hematologic malignancy and solid cancers. In this group, HFNC reduced the likelihood of intubation but had no significant effect on mortality [17]. Currently the HIGH study is enrolling patients to evaluate the survival benefit of HFNC in immunocompromised patients. This will be the largest multicenter, randomized controlled trial to date evaluating HFNC in cancer patients. The study completion date is estimated December 2018 [18].

Failure rates of NIV in the cancer patient vary widely from $25 \%$ up to $70 \%[14,45,161]$. Unfortunately, data consistently indicate that 
outcomes are far worse following failure of NIV $[41,122,181]$. Whether this is due to delay of intubation, inappropriate utilization of NIV in a poorly monitored ward, impact of NiPPV on transpulmonary pressures with resultant volume and barotrauma, or other patient specific characteristics is not fully elucidated.

Previous studies have evaluated risk factors for failure of NIV in cancer patients. Such risks include high illness severity scores, presence of ARDS or multifocal lung involvement, prolonged duration of NIV, septic shock or concomitant use of vasoactive agents, male gender, high respiratory rate, and presence of documented pulmonary infection $[11,71]$ Within the last 2 years, predictive models have been created to assess a patient's risk for failing NIV. The HACOR score is one such model. This validated score ranging from 0 to 25 points takes into account the following variables of heart rate, acidosis, level of consciousness, oxygenation, and respiratory rate. Rate of failure of NIV in a patient scoring $<5$ is only $18 \%$, whereas a score $>5$ predicts failure of NIV in $78 \%$ [65].

Truly this exemplifies the need for appropriate patient selection and to ascertain the cause of acute respiratory failure as indiscriminate application of NIV may be harmful. If used for hypoxemia, NIV should be restricted to areas of high monitoring (ICU level care) and performed early with a time sensitive trial and only in the absence of risk factors that portend high likelihood of failure. Such use is consistent with the use of NIV in the general population as outlined by the American Thoracic Society and European Respiratory Society. Otherwise NIV should be utilized in situations of established benefit such as hypercapnic respiratory failure, cardiogenic pulmonary edema, and in those patients with respiratory failure in the postoperative setting [146]. Many patients present advance directives that preclude the use of mechanical ventilation. In these patients, it is reasonable to utilize NIV or even HFNC. Much as in ARDS, there is no place for non-invasive ventilation in cancer patients with hypoxemic respiratory failure and high risk of NIV failure. Such patients should simply be intubated and mechanically ventilated.

\section{Preparation for Mechanical Ventilation}

Patients with risk factors predicting failure of NIV, or in whom emergent airway management is needed, are candidates for invasive mechanical ventilation. The specifics of ventilator setup, different modes and indications, prolonged ventilator management and tracheostomy, postoperative considerations, weening, and ventilator specific strategies for treatment of refractory hypoxemia are beyond the scope of this chapter. These subjects require chapters (or books) dedicated to each topic. Rather, this section will cover the challenges and strategic evaluation of the cancer patient in preparation for transition to invasive positive pressure ventilation. For further reading, Walz et al. provide a comprehensive review of airway management in critical illness including preparation, drug selection, and algorithmic approach to the difficulty and failed airway [182].

Foremost the reason for ARF must be established and the appropriateness of noninvasive therapies must be weighed against the severity of illness and the potential risks of establishing an airway and proceeding with mechanical ventilation. Aside from physiologic challenges of respiratory failure, anatomic difficulties are frequent in the cancer population. This is exemplified in the case of a patient with head and neck squamous cell cancer and acute upper airway obstruction. Such anatomical distortion needs to be considered to minimize potential complications and avoid a situation in which one cannot oxygenate nor ventilate. The rate of complications of airway management differs by clinical setting. Failed intubation happens rarely (1 in 2000) in elective surgical cases in the controlled arena of the operating theatre. This number is far more frequent in the emergency department and ICU setting and failed intubation may occur in one of every $50 \mathrm{ICU}$ patients [53]. In every patient requiring intubation and mechanical ventilation predictors of difficulty anatomy and physiology should be sought prior to initiating rapid sequence intubation (RSI). Indeed, RSI may be detrimental to securing the airway in selected patients with severe hypoxemia, right heart failure, hemodynamic instability, or profound obesity [123]. 
For initial evaluation of the difficult anatomic airway, the mnemonic LEMON is often used. This approach has the clinician evaluate for anatomical difficulties by Looking externally for unusual anatomy, body habitus, scars, etc., Evaluating incisor distance, the length from hyoid to mentum, and the thyroid to mouth, and assessing jaw mobility and mouth opening. Next the Mallampati score is determined on the classic I-IV scale. Class III and above predict a difficult intubation. Obstruction sought out next, especially in the patient with head and neck cancer. Finally, impairment in Neck mobility also presents an anatomic challenge to successful first pass endotracheal intubation. Neck mobility in cancer patients may occur due to prior surgery or as sequela of radiation therapy. If the difficulty anatomic airway is predicted and time allots, it is prudent to seek airway expertise or consider an awake, fiber optic intubation.

Physiologic challenges to establishing an airway are often overlooked, but of the utmost importance. Three physiologically difficult characteristics have been described including hypoxemia, hypotension, and right heart failure. Hypoxemic patients are at risk for rapid desaturation during intubation. Tissue hypoxia implies impaired oxygen delivery or grossly exaggerated oxygen consumption, often both. In a patient with central obesity, the oxygen reserve or functional residual capacity (FRC) is reduced, and when this patient is struck with hypoxia, the time to desaturation during RSI is rapid. It is suggested that if time permits, every patient undergo a period of preoxygenation prior to intubation [172], preferably with NIV [21]. Note that the indication for NIV in this instance is for preparation for mechanical ventilation. NIV has been shown to improve preoxygenation and end-tidal oxygen far better than standard oxygen alone $[21,164]$. Once apneic, implementation of "diffusion respiration" or apneic oxygenation provides a buffer against hypoxia by providing a steady flow of oxygen though the upper airway which passively diffuses to the alveoli as oxygen is taken up into the blood stream [173]. HFNC is purportedly an ideal method of diffusion respiration [183]. While prolonged NIV and HFNC may not be appropriate therapy for hypoxemia, their place may be upheld in preparation for securing the airway for mechanical ventilation.

Many patients with malignancy present with both hypoxia and hypotension which presents challenges to establishing endotracheal intubation. This combination especially frequent and challenging in the cancer patient as hypotension is common. Side effects of chemotherapy predispose to volume loss by vomiting and dehydration [29]. Sequestration of intravascular fluid into the interstitium occurs later in disease as proteincalorie malnutrition becomes common. Sepsis, cytokine storm from novel therapy, pulmonary embolism, blood loss, and more may contribute to a state of poor perfusion which in turn imparts increased oxygen extraction and subsequent hypoxemia. Hypoxemia may contribute to tissue hypoxia and subsequent metabolic acidosis. This acidic milieu can impair the effect of native catecholamines and thereby worsen hypotension [30]. The negative intrathoracic pressure of spontaneous respiration acts to pull blood from the venous reservoir and increase venous return. Transition to positive pressure increases intrathoracic pressure and reduces this venous return. As such, a patient teetering on the brink may be subject to further hypotension as a result of commonly used induction agents or the implementation of positive pressure ventilation $[75,76]$. As many as $30 \%$ of critically ill patients experience cardiovascular collapse following intubation [135]. This in turn contributes to longer runs of mechanical ventilation and increased ICU stay which can be detrimental to the immunocompromised cancer patient $[75,76,86,124]$. Assessment of volume status and appropriate resuscitation and consideration of vasopressor infusion may be appropriate in the peri-intubation phase of the critically ill cancer patient requiring endotracheal intubation [123].

A brief note should be made regarding airway management with hypotension and hypoxia in the setting of right heart failure. Such physiology may develop as a result of pulmonary emboli, pulmonary hypertension, or cor pulmonale from any cause of hypoxemia in the cancer patient. Much like the pulmonary circulation, the right 
ventricle is a low-pressure, high-compliance pump. However, it has limited ability to adapt to acute insult. Hypotension due to right heart failure needs careful evaluation prior to initiation of positive pressure ventilation as increased intrathoracic pressure also increases right ventricular afterload. Hypoxia from ARF induces pulmonary vascular vasoconstriction which places further strain on an ailing RV. Measures normally thought of to restore perfusion pressures such as volume resuscitation or vasoactive agents may further impede RV function and perpetuate poor LV filling and hypotension. If RV dysfunction is suspected prior to intubation, bedside echocardiography should be performed to evaluate for signs of RV failure. In this situation, avoidance of hypoxemia with preoxygenation and apneic oxygenation are a must, and consider "blood pressure neutral" drugs for induction. Initial ventilator settings should target a lower mean airway pressure (if possible) until further stabilization. If available prior to intubation, one may consider application of inhaled nitric oxide or inhaled epoprostenol to improve V/Q mismatch and augment RV unloading and LV filling [123].

\section{Treatment Strategies for Hypercapnic Respiratory Failure}

Initial therapies for type II respiratory failure should be implemented at the bedside with attention to instigating causes. Many cancer patients take opioid narcotics for pain control. While a 2011 study identified that opioid related death is less common in cancer patients than in those taking narcotics for other reasons [31], the high doses of opioid often required to control malignant pain may subject one to hypoventilation and subsequent respiratory failure. A trial of naloxone is reasonable and avoidance of sedatives is recommended. Care should be taken if attempting to reverse benzodiazepines as GABA antagonism may precipitate seizures in those patients with chronic use [5, 108].

Patients with hypercapnic respiratory failure may benefit from a trial of NIV. In cases of COPD exacerbation, therapy with NIV should be utilized early before the onset of acute respiratory acidosis. Suitable candidates for NIV in acute hypercapnia are those who are conscious and able to follow commands and have signs of respiratory distress, a $\mathrm{pH}<7.35$ but greater than 7.20 , and in whom close monitoring may occur. It should not be used as first line therapy in patients that are hemodynamically unstable, have multiorgan failure, severe hypoxemia or academia, encephalopathy, or are unable to follow commands, or in whom cardiac or respiratory arrest has occurred.

Optimal settings depend on the patient's body habitus and weight, degree of acidosis, and patient tolerance. Pressure controlled bilevel positive pressure is often used, though volume controlled NIV is also an option.

Frequent monitoring of the patient's clinical condition and arterial blood gas is a must as indiscriminate use of NIV can result in overcorrection and subsequent alkalemia. A time-limited trial should be performed, and if the patient worsens or develops contraindications to NIV, this therapy should be discontinued and mechanical ventilation initiated.

Extracorporeal carbon dioxide removal through a venovenous approach is available at some centers. Unfortunately many centers view active malignancy as a contraindication for extracorporeal membrane support of either oxygenation or $\mathrm{CO}_{2}$ removal.

\section{Ventilatory Therapies for Hypoxemic Respiratory Failure}

Using the acute respiratory distress as a model for severe hypoxemia, there are basic principles of mechanical ventilation that afford a survival benefit. A "lung-protective" strategy should be implemented with tidal volumes of $4-8 \mathrm{ml} / \mathrm{kg}$ ideal body weight, as well as selecting a modest level of positive end expiratory pressure (PEEP) and making best efforts to limit plateau pressures (in a volume targeted mode of ventilation) to less than $30 \mathrm{cmH}_{2} \mathrm{O}$ [1]. Such remains the current standard of care despite studies over the last decade challenging this dogma. Once severe hypoxemia occurs, emphasis should be on providing 
Table 5 Selection of PEEP based on required $\mathrm{FiO}_{2}$. (Adapted from ARDSnet)

Lower PEEP and higher $\mathrm{FiO}_{2}$

\begin{tabular}{|c|c|c|c|c|c|c|c|c|c|}
\hline $\mathrm{FiO}_{2}$ & 0.3 & 0.4 & 0.4 & 0.5 & 0.5 & 0.6 & 0.7 & 0.7 & 0.7 \\
\hline PEEP & 5 & 5 & 8 & 8 & 10 & 10 & 10 & 12 & 14 \\
\hline $\mathrm{FiO}_{2}$ & 0.8 & 0.9 & 0.9 & 0.9 & 1.0 & & & & \\
\hline PEEP & 14 & 14 & 16 & 18 & $18-24$ & & & & \\
\hline \multicolumn{10}{|c|}{ Higher PEEP and lower $\mathrm{FiO}_{2}$} \\
\hline $\mathrm{FiO}_{2}$ & 0.3 & 0.3 & 0.3 & 0.3 & 0.3 & 0.4 & 0.4 & 0.5 & 0.5 \\
\hline PEEP & 5 & 8 & 10 & 12 & 14 & 14 & 16 & 16 & 18 \\
\hline $\mathrm{FiO}_{2}$ & $0.5-0.8$ & 0.8 & 0.9 & 1.0 & 1.0 & & & & \\
\hline PEEP & 20 & 22 & 22 & 22 & 24 & & & & \\
\hline
\end{tabular}

adequate oxygenation while attempting to reduce or eliminate ventilator-induced lung injury. Whether pressure or volume targeted therapy is used, selection of appropriate PEEP may be especially important in the patient with suspected chemotherapy or radiation-induced lung injury as it may obviate the need for injurious levels of inspired oxygen [37, 80, 117]. While the three major studies in this area (ALVEOLI, LOV and EXPRESS) reported no survival benefit, they did demonstrate improvements in $\mathrm{PaO}_{2} / \mathrm{FiO}_{2}$. Many strategies to select PEEP area available, including incremental trial of PEEP, decremental selection of PEEP, and observation of the pressure-time curve during constant flow volume targeted ventilation (stress index) [80]. For simplicity, the ARDS Clinical Trial Network has created a table with suggested degrees of PEEP based on requirements for $\mathrm{FiO}_{2}$ (Table 5).

Other modalities of ventilation may be utilized in cases of refractory hypoxemia. Such modalities, termed "rescue therapies," are associated with improvements in arterial oxygen tension, but not survival. These include such strategies as airway pressure release ventilation, recruitment maneuvers, and extracorporeal membrane oxygenation [68]. Some recent data are challenging the belief that recruitment maneuvers are beneficial and even implicate them causing harm (Writing Group for the Alveolar Recruitment for Acute Respiratory Distress Syndrome Trial et al. [185]). In addition, most centers offering ECMO consider active or incurable malignancy as a contraindication to this service; thus, it is unfortunately unavailable for many cancer patients [109].

\section{Prognosis}

Whether or not to admit a patient with potentially severe illness to the ICU is a central dilemma faced by intensivists. Preconceived notions are difficult to abolish. Twenty years ago mechanical ventilation following bone marrow transplanted was associated with a mere $2-6 \%$ chance of survival. In this study from 1992, the authors elaborated that of 348 bone marrow transplant patients requiring mechanical ventilation, none survived if they required mechanical ventilation for more than 9 days [59]. Further studies in the early 1990s demonstrated high mortality rates of cancer patients in medical intensive care units $[35,151]$. This perpetuated a mentality that admission of such patients to the ICU was futile care. Indeed attitudes toward the care of critically ill oncology patients vary by medical subspecialty [130]. Whereas intensivists may focus on organ failure and retain pessimistic notions of the outcomes of critically ill cancer patients [25], oncologists emphasize aspects of cancer therapy and tend to overestimate survival of oncologic patients with acute respiratory failure [50]. Therefore, a multidisciplinary approach with frequent communication between ICU teams, oncology, and palliative care is vital to minimize misconceptions and clarify viewpoints of patient care. Such comprehensive multidisciplinary care is associated with improved survival in this population [101].

In the last 25 years, the morality rates of cancer patients admitted to the ICU have improved and approached that of the general population (30-65\%) [61, 159-161]. The notion of cancer 
as a chronic illness should be upheld when considering admission of the oncology patient to the ICU. Excluding individuals with hematopoietic stem cell transplant, oncology patients requiring mechanical ventilation for ARF have a $40 \%$ mortality rate. For perspective, a 2004 study identified a $38 \%$ mortality rate for chronic obstructive pulmonary disease patients undergoing mechanical ventilation for exacerbation of COPD [100]. Short term prognosis in critically ill adult oncology now depends on the nature of the acute illness rather than the stage of malignancy or by the complications of cancer therapy $[27,90,116]$.

For patients with solid and hematologic malignancy, short term survival is best predicted by the type and number of organ failure [61, 152]. Highest rates of mortality is in those patients requiring mechanical ventilation [152]. When diagnosed with the acute respiratory distress syndrome, mortality rates may exceed $60 \%[16,145]$. Similarly, adult HCT recipients that require endotracheal intubation have mortality rates near 70\% [6]. Variation between studies may be attributed to differences in indication for mechanical ventilation. However, several factors have been identified that portend an especially poor prognosis. These include respiratory failure from a poorly reversible cause [159], underlying chronic pulmonary illness [24], severe hypoxemia prior to intubation $\left(\mathrm{PaO}_{2}<50 \mathrm{mmHg}\right)$ [81], and prolonged need for mechanical ventilation [69]. In addition, a small study including patients undergoing chemotherapy while intubated in the ICU revealed an $87 \%$ mortality rate [61].

In those that survive ICU stay, 6-month outcomes are worse if mechanical ventilation was required. In a retrospective study of 37 patients with hematologic malignancy, only $36 \%$ of those surviving mechanical ventilation were alive 6 months post-ICU care [28].

\section{References}

1. Acute Respiratory Distress Syndrome Network, Brower RG, Matthay MA, Morris A, Schoenfeld D, Thompson BT, Wheeler A. Ventilation with lower tidal volumes as compared with traditional tidal volumes for acute lung injury and the acute respiratory distress syndrome. N Engl J Med. 2000;342:1301-8. https://doi.org/10.1056/NEJM200005043421801.

2. Afessa B, Abdulai RM, Kremers WK, Hogan WJ, Litzow MR, Peters SG. Risk factors and outcome of pulmonary complications after autologous hematopoietic stem cell transplant. Chest. 2012;141: 442-50. https://doi.org/10.1378/chest.10-2889.

3. Akira M. Computed tomography and pathologic findings in fulminant forms of idiopathic interstitial pneumonia. J Thorac Imaging. 1999;14:76-84.

4. Alasaly K, Muller N, Ostrow DN, Champion P, FitzGerald JM. Cryptogenic organizing pneumonia. A report of 25 cases and a review of the literature. Medicine (Baltimore). 1995;74:201-11.

5. Albiero A, Brigo F, Faccini M, Casari R, Quaglio G, Storti M, Fiaschi A, Bongiovanni LG, Lugoboni F. Focal nonconvulsive seizures during detoxification for benzodiazepine abuse. Epilepsy Behav. 2012;23: 168-70. https://doi.org/10.1016/j.yebeh.2011.11.005.

6. Allareddy V, Roy A, Rampa S, Lee MK, Nalliah RP, Allareddy V, Rotta AT. Outcomes of stem cell transplant patients with acute respiratory failure requiring mechanical ventilation in the United States. Bone Marrow Transplant. 2014;49:1278-86. https://doi. org/10.1038/bmt.2014.130.

7. Amato MB, Meade MO, Slutsky AS, Brochard L, Costa EL, Schoenfeld DA, Stewart TE, Briel M, Talmor D, Mercat A, Richard JC, Carvalho CR, Brower RG. Driving pressure and survival in the acute respiratory distress syndrome. N Engl J Med. 2015;372:747-55. https://doi.org/10.1056/NEJMsa1 410639.

8. Antonelli M, Conti G, Bufi M, Costa MG, Lappa A, Rocco M, Gasparetto A, Meduri GU. Noninvasive ventilation for treatment of acute respiratory failure in patients undergoing solid organ transplantation: a randomized trial. JAMA. 2000;283:235-41.

9. Artigas A, Bernard GR, Carlet J, Dreyfuss D, Gattinoni L, Hudson L, Lamy M, Marini JJ, Matthay MA, Pinsky MR, Spragg R, Suter PM. The American-European Consensus Conference on ARDS, part 2: ventilatory, pharmacologic, supportive therapy, study design strategies, and issues related to recovery and remodeling. Acute respiratory distress syndrome. Am J Respir Crit Care Med. 1998a;157:1332-47. https://doi.org/10.1164/ajrccm. 157.4.ats2-98.

10. Artigas A, Bernard GR, Carlet J, Dreyfuss D, Gattinoni L, Hudson L, Lamy M, Marini JJ, Matthay MA, Pinsky MR, Spragg R, Suter PM. The American-European Consensus Conference on ARDS, part 2. Ventilatory, pharmacologic, supportive therapy, study design strategies and issues related to recovery and remodeling. Intensive Care Med. 1998b;24:378-98.

11. Azevedo LCP, Caruso P, Silva UVA, Torelly AP, Silva E, Rezende E, Netto JJ, Piras C, Lobo SMA, Knibel MF, Teles JM, Lima RA, Ferreira BS, Friedman G, Rea-Neto A, Dal-Pizzol F, Bozza FA, 
Salluh JIF, Soares M. Outcomes for patients with cancer admitted to the ICU requiring ventilatory support: results from a prospective multicenter study. Chest. 2014;146:257-66. https://doi.org/10.1378/ chest.13-1870. S0012-3692(15)48814-2 [pii].

12. Azoulay E, Schlemmer B. Diagnostic strategy in cancer patients with acute respiratory failure. Intensive Care Med. 2006;32:808-22. https://doi.org/10.1007/ s00134-006-0129-2.

13. Azoulay E, Alberti C, Bornstain C, Leleu G, Moreau D, Recher C, Chevret S, Le Gall JR, Brochard L, Schlemmer B. Improved survival in cancer patients requiring mechanical ventilatory support: impact of noninvasive mechanical ventilatory support. Crit Care Med. 2001;29:519-25.

14. Azoulay E, Thiery G, Chevret S, Moreau D, Darmon M, Bergeron A, Yang K, Meignin V, Ciroldi M, Le Gall JR, Tazi A, Schlemmer B. The prognosis of acute respiratory failure in critically ill cancer patients. Medicine (Baltimore). 2004;83: 360-70. 00005792-200411000-00005 [pii].

15. Azoulay E, Mokart D, Lambert J, Lemiale V, Rabbat A, Kouatchet A, Vincent F, Gruson D, Bruneel F, Epinette-Branche G, Lafabrie A, Hamidfar-Roy R, Cracco C, Renard B, Tonnelier JM, Blot F, Chevret S, Schlemmer B. Diagnostic strategy for hematology and oncology patients with acute respiratory failure: randomized controlled trial. Am J Respir Crit Care Med. 2010;182:1038-46. https://doi.org/10.1164/rccm.20 1001-0018OC. 201001-0018OC [pii].

16. Azoulay E, Mokart D, Pene F, Lambert J, Kouatchet A, Mayaux J, Vincent F, Nyunga M, Bruneel F, Laisne LM, Rabbat A, Lebert C, Perez P, Chaize M, Renault A, Meert AP, Benoit D, Hamidfar R, Jourdain M, Darmon M, Schlemmer B, Chevret S, Lemiale V. Outcomes of critically ill patients with hematologic malignancies: prospective multicenter data from France and Belgium - a groupe de recherche respiratoire en reanimation oncohematologique study. J Clin Oncol. 2013;31: 2810-8. https://doi.org/10.1200/JCO.2012.47.2365. JCO.2012.47.2365 [pii].

17. Azoulay E, Pickkers P, Soares M, Perner A, Rello J, Bauer PR, van de Louw A, Hemelaar P, Lemiale V, Taccone FS, Martin Loeches I, Meyhoff TS, Salluh J, Schellongowski P, Rusinova K, Terzi N, Mehta S, Antonelli M, Kouatchet A, Barratt-Due A, Valkonen M, Landburg PP, Bruneel F, Bukan RB, Pene F, Metaxa V, Moreau AS, Souppart V, Burghi G, Girault C, Silva UVA, Montini L, Barbier F, Nielsen LB, Gaborit B, Mokart D, Chevret S, Efraim investigators and the Nine-I study group. Acute hypoxemic respiratory failure in immunocompromised patients: the Efraim multinational prospective cohort study. Intensive Care Med. 2017;43:1808-19. https://doi.org/10.1007/s00134017-4947-1.
18. Azoulay E, Lemiale V, Mokart D, Nseir S, Argaud L, Pene F, Kontar L, Bruneel F, Klouche K, Barbier F, Reignier J, Stoclin A, Louis G, Constantin JM, Mayaux J, Wallet F, Kouatchet A, Peigne V, Perez P, Girault C, Jaber S, Oziel J, Nyunga M, Terzi N, Bouadma L, Lebert C, Lautrette A, Bige N, Raphalen JH, Papazian L, Rabbat A, Darmon M, Chevret S, Demoule A. High-flow nasal oxygen vs. standard oxygen therapy in immunocompromised patients with acute respiratory failure: study protocol for a randomized controlled trial. Trials. 2018;19:157. https://doi.org/10.1186/s13063-018-2492-z.

19. Bach PB, Giralt SA, Saltz LB. FDA approval of tisagenlecleucel: promise and complexities of a $\$ 475000$ cancer drug. JAMA. 2017;318:1861-2. https://doi.org/10.1001/jama.2017.15218.

20. Baddley JW, Andes DR, Marr KA, Kontoyiannis DP, Alexander BD, Kauffman CA, Oster RA, Anaissie EJ, Walsh TJ, Schuster MG, Wingard JR, Patterson TF, Ito JI, Williams OD, Chiller T, Pappas PG. Factors associated with mortality in transplant patients with invasive aspergillosis. Clin Infect Dis. 2010;50: 1559-67. https://doi.org/10.1086/652768.

21. Baillard C, Fosse JP, Sebbane M, Chanques G, Vincent F, Courouble P, Cohen Y, Eledjam JJ, Adnet F, Jaber S. Noninvasive ventilation improves preoxygenation before intubation of hypoxic patients. Am J Respir Crit Care Med. 2006;174:171-7. https:// doi.org/10.1164/rccm.200509-1507OC.

22. Balaji A, Verde F, Suresh K, Naidoo J. Pneumonitis from anti-PD-1/PD-L1 therapy. Oncology (Williston Park). 2017;31:739-46, 754.

23. Barberi S, Ciprandi G, Verduci E, D'Auria E, Poli P, Pietra B, Incorvaia C, Buttafava S, Frati F, Riva E. Effect of high-dose sublingual immunotherapy on respiratory infections in children allergic to house dust mite. Asia Pac Allergy. 2015;5:163-9. https:// doi.org/10.5415/apallergy.2015.5.3.163.

24. Bayraktar UD, Shpall EJ, Liu P, Ciurea SO, Rondon G, de Lima M, Cardenas-Turanzas M, Price KJ, Champlin RE, Nates JL. Hematopoietic cell transplantation-specific comorbidity index predicts inpatient mortality and survival in patients who received allogeneic transplantation admitted to the intensive care unit. J Clin Oncol. 2013;31:4207-14. https://doi.org/10.1200/JCO.2013.50.5867.

25. Benekli M. Challenging decision: ICU admission of critically ill elderly solid tumor patients. J Thorac Dis. 2017;9:3564-7. https://doi.org/10.21037/jtd.201 7.09.25.

26. Benoit DD, Depuydt PO. Outcome in critically ill cancer patients: past and present. Rev Bras Ter Intensiva. 2008;20:82-7.

27. Benoit DD, Vandewoude KH, Decruyenaere JM, Hoste EA, Colardyn FA. Outcome and early prognostic indicators in patients with a hematologic malignancy admitted to the intensive care unit for a life-threatening complication. Crit Care Med. 2003; 
31:104-12. https://doi.org/10.1097/01.CCM.000003 8213.27741.30.

28. Benoit DD, Depuydt PO, Vandewoude KH, Offner FC, Boterberg T, De Cock CA, Noens LA, Janssens AM, Decruyenaere JM. Outcome in severely ill patients with hematological malignancies who received intravenous chemotherapy in the intensive care unit. Intensive Care Med. 2006;32:93-9. https:// doi.org/10.1007/s00134-005-2836-5.

29. Berk L, Rana S. Hypovolemia and dehydration in the oncology patient. J Support Oncol. 2006;4:447-54; discussion 455-7.

30. Biais M, Jouffroy R, Carillion A, Feldman S, Jobart-Malfait A, Riou B, Amour J. Interaction of metabolic and respiratory acidosis with alpha and beta-adrenoceptor stimulation in rat myocardium. Anesthesiology. 2012;117:1212-22. https://doi.org/ 10.1097/ALN.0b013e3182753264.

31. Bohnert AS, Valenstein M, Bair MJ, Ganoczy D, McCarthy JF, Ilgen MA, Blow FC. Association between opioid prescribing patterns and opioid overdose-related deaths. JAMA. 2011;305:1315-21. https://doi.org/10.1001/jama.2011.370.

32. Bos MM, Verburg IW, Dumaij I, Stouthard J, Nortier JW, Richel D, van der Zwan EP, de Keizer NF, de Jonge E. Intensive care admission of cancer patients: a comparative analysis. Cancer Med. 2015;4:966-76. https://doi.org/10.1002/cam4.430.

33. Boshkov LK. Transfusion-related acute lung injury and the ICU. Crit Care Clin. 2005;21:479-95. https:// doi.org/10.1016/j.ccc.2005.05.005.

34. Bovelli D, Plataniotis G, Roila F, ESMO Guidelines Working Group. Cardiotoxicity of chemotherapeutic agents and radiotherapy-related heart disease: ESMO Clinical Practice Guidelines. Ann Oncol. 2010; 21(Suppl 5):v277-82. https://doi.org/10.1093/ annonc/mdq200.

35. Brenner H. Long-term survival rates of cancer patients achieved by the end of the 20th century: a period analysis. Lancet. 2002;360:1131-5. https:// doi.org/10.1016/S0140-6736(02)11199-8.

36. Brochard L, Lefebvre JC, Cordioli RL, Akoumianaki E, Richard JC. Noninvasive ventilation for patients with hypoxemic acute respiratory failure. Semin Respir Crit Care Med. 2014;35:492-500. https://doi.org/10.1055/s-0034-1383863.

37. Brower RG, Lanken PN, MacIntyre N, Matthay MA, Morris A, Ancukiewicz M, Schoenfeld D, Thompson BT, National Heart, Lung, and Blood Institute ARDS Clinical Trials Network. Higher versus lower positive end-expiratory pressures in patients with the acute respiratory distress syndrome. N Engl J Med. 2004;351:327-36. https://doi.org/ 10.1056/NEJMoa032193.

38. Brudno JN, Kochenderfer JN. Toxicities of chimeric antigen receptor $\mathrm{T}$ cells: recognition and management. Blood. 2016;127:3321-30. https://doi. org/10.1182/blood-2016-04-703751.
39. Campbell JH, Raina V, Banham SW, Cunningham D, Soukop M. Pulmonary infiltrates - diagnostic problems in lymphoma. Postgrad Med J. 1989;65:881-4.

40. Cazzadori A, Di Perri G, Todeschini G, Luzzati R, Boschiero L, Perona G, Concia E. Transbronchial biopsy in the diagnosis of pulmonary infiltrates in immunocompromised patients. Chest. 1995;107: 101-6.

41. Chandra D, Stamm JA, Taylor B, Ramos RM, Satterwhite L, Krishnan JA, Mannino D, Sciurba FC, Holguin F. Outcomes of noninvasive ventilation for acute exacerbations of chronic obstructive pulmonary disease in the United States, 1998-2008. Am J Respir Crit Care Med. 2012;185:152-9. https://doi.org/10.11 64/rccm.201106-1094OC.

42. Chaoui D, Legrand O, Roche N, Cornet M, Lefebvre A, Peffault de Latour R, Sanhes L, Huchon G, Marie JP, Rabbat A. Incidence and prognostic value of respiratory events in acute leukemia. Leukemia. 2004;18:670-5. https://doi.org/ 10.1038/sj.leu.2403270.

43. Chaparro C, Chamberlain D, Maurer J, Winton T, Dehoyos A, Kesten S. Bronchiolitis obliterans organizing pneumonia (BOOP) in lung transplant recipients. Chest. 1996;110:1150-4.

44. Chemaly RF, Torres HA, Hachem RY, Nogueras GM, Aguilera EA, Younes A, Luna MA, Rodriguez G, Tarrand JJ, Raad II. Cytomegalovirus pneumonia in patients with lymphoma. Cancer. 2005;104:1213-20. https://doi.org/10.1002/cncr.21294.

45. Chen WC, Su VY, Yu WK, Chen YW, Yang KY. Prognostic factors of noninvasive mechanical ventilation in lung cancer patients with acute respiratory failure. PLoS One. 2018;13:e0191204. https://doi. org/10.1371/journal.pone.0191204.

46. Chi DC, Brogan F, Turenne I, Zelonis S, Schwartz L, Saif MW. Gemcitabine-induced pulmonary toxicity. Anticancer Res. 2012;32:4147-9.

47. Chi AK, Soubani AO, White AC, Miller KB. An update on pulmonary complications of hematopoietic stem cell transplantation. Chest. 2013;144:1913-22. https://doi.org/10.1378/chest.12-1708.

48. Clark JG, Hansen JA, Hertz MI, Parkman R, Jensen L, Peavy HH. NHLBI workshop summary. Idiopathic pneumonia syndrome after bone marrow transplantation. Am Rev Respir Dis. 1993;147:1601-6. https:// doi.org/10.1164/ajrccm/147.6_Pt_1.1601.

49. Clarke M, Collins R, Darby S, Davies C, Elphinstone P, Evans V, Godwin J, Gray R, Hicks C, James S, MacKinnon E, McGale P, McHugh T, Peto R, Taylor C, Wang Y, Early Breast Cancer Trialists' Collaborative Group (EBCTCG). Effects of radiotherapy and of differences in the extent of surgery for early breast cancer on local recurrence and 15-year survival: an overview of the randomised trials. Lancet. 2005;366:2087-106. https://doi.org/ 10.1016/S0140-6736(05)67887-7.

50. Clement-Duchene C, Carnin C, Guillemin F, Martinet Y. How accurate are physicians in the 
prediction of patient survival in advanced lung cancer? Oncologist. 2010;15:782-9. https://doi.org/ 10.1634/theoncologist.2009-0149.

51. Clifford L, Jia Q, Subramanian A, Yadav H, Schroeder DR, Kor DJ. Risk factors and clinical outcomes associated with perioperative transfusionassociated circulatory overload. Anesthesiology. 2017;126:409-18. https://doi.org/10.1097/ALN.000 0000000001506 .

52. Coggle JE, Lambert BE, Moores SR. Radiation effects in the lung. Environ Health Perspect. 1986;70:261-91.

53. Cook TM, MacDougall-Davis SR. Complications and failure of airway management. $\mathrm{Br} \mathrm{J}$ Anaesth. 2012;109(Suppl 1):i68-85. https://doi.org/10.1093/ bja/aes393.

54. Cordier JF. Cryptogenic organising pneumonia. Eur Respir J. 2006;28:422-46. https://doi.org/10.1183/ 09031936.06.00013505.

55. Cornell RF, Hari P, Drobyski WR. Engraftment syndrome after autologous stem cell transplantation: an update unifying the definition and management approach. Biol Blood Marrow Transplant. 2015;21: 2061-8. https://doi.org/10.1016/j.bbmt.2015.08.030.

56. Cottin V, Cordier JF. Cryptogenic organizing pneumonia. Semin Respir Crit Care Med. 2012; 33:462-75. https://doi.org/10.1055/s-0032-1325157.

57. Craven DE, Steger KA. Nosocomial pneumonia in the intubated patient. New concepts on pathogenesis and prevention. Infect Dis Clin North Am. 1989;3:843-66.

58. Craven DE, Kunches LM, Kilinsky V, Lichtenberg DA, Make BJ, McCabe WR. Risk factors for pneumonia and fatality in patients receiving continuous mechanical ventilation. Am Rev Respir Dis. 1986;133:792-6.

59. Crawford SW, Petersen FB. Long-term survival from respiratory failure after marrow transplantation for malignancy. Am Rev Respir Dis. 1992;145:510-4. https://doi.org/10.1164/ajrccm/145.3.510.

60. Cuttner J, Conjalka MS, Reilly M, Goldberg J, Reisman A, Meyer RJ, Holland JF. Association of monocytic leukemia in patients with extreme leukocytosis. Am J Med. 1980;69:555-8.

61. Darmon M, Thiery G, Ciroldi M, de Miranda S, Galicier L, Raffoux E, Le Gall JR, Schlemmer B, Azoulay E. Intensive care in patients with newly diagnosed malignancies and a need for cancer chemotherapy. Crit Care Med. 2005;33:2488-93. 00003246-200511000-00007 [pii].

62. Daver N, Kantarjian H, Marcucci G, Pierce S, Brandt M, Dinardo C, Pemmaraju N, GarciaManero G, O'Brien S, Ferrajoli A, Verstovsek S, Popat U, Hosing C, Anderlini P, Borthakur G, Kadia T, Cortes J, Ravandi F. Clinical characteristics and outcomes in patients with acute promyelocytic leukaemia and hyperleucocytosis. Br J Haematol. 2015;168:646-53. https://doi.org/10.1111/bjh.13189.
63. de la Hoz RE, Stephens G, Sherlock C. Diagnosis and treatment approaches of CMV infections in adult patients. J Clin Virol. 2002;25(Suppl 2):S1-12.

64. Depuydt PO, Benoit DD, Roosens CD, Offner FC, Noens LA, Decruyenaere JM. The impact of the initial ventilatory strategy on survival in hematological patients with acute hypoxemic respiratory failure. J Crit Care. 2010;25:30-6. https://doi.org/10.1016/j. jcrc.2009.02.016. S0883-9441(09)00131-2 [pii].

65. Duan J, Han X, Bai L, Zhou L, Huang S. Assessment of heart rate, acidosis, consciousness, oxygenation, and respiratory rate to predict noninvasive ventilation failure in hypoxemic patients. Intensive Care Med. 2017;43:192-9. https://doi.org/10.1007/s00134-0164601-3.

66. Ellis DA, Capewell SJ. Pulmonary veno-occlusive disease after chemotherapy. Thorax. 1986;41:415-6.

67. Epstein AS, Hartridge-Lambert SK, Ramaker JS, Voigt LP, Portlock CS. Humidified high-flow nasal oxygen utilization in patients with cancer at Memorial Sloan-Kettering Cancer Center. J Palliat Med. 2011; 14:835-9. https://doi.org/10.1089/jpm.2011. 0005.

68. Esan A, Hess DR, Raoof S, George L, Sessler CN. Severe hypoxemic respiratory failure: part 1 - ventilatory strategies. Chest. 2010;137:1203-16. https:// doi.org/10.1378/chest.09-2415.

69. Ewer MS, Ali MK, Atta MS, Morice RC, Balakrishnan PV. Outcome of lung cancer patients requiring mechanical ventilation for pulmonary failure. JAMA. 1986;256:3364-6.

70. Faria IM, Zanetti G, Barreto MM, Rodrigues RS, Araujo-Neto CA, Silva JL, Escuissato DL, Souza AS Jr, Irion KL, Mancano AD, Nobre LF, Hochhegger B, Marchiori E. Organizing pneumonia: chest HRCT findings. J Bras Pneumol. 2015;41: 231-7. https://doi.org/10.1590/S1806-37132015000 004544.

71. Ferreira JC, Medeiros P Jr, Rego FM, Caruso P. Risk factors for noninvasive ventilation failure in cancer patients in the intensive care unit: a retrospective cohort study. J Crit Care. 2015;30:1003-7. https:// doi.org/10.1016/j.jcrc.2015.04.121.

72. Ferrer M, Esquinas A, Leon M, Gonzalez G, Alarcon A, Torres A. Noninvasive ventilation in severe hypoxemic respiratory failure: a randomized clinical trial. Am J Respir Crit Care Med. 2003; 168:1438-44. https://doi.org/10.1164/rccm.200301$072 \mathrm{OC}$.

73. Franquet T, Muller NL, Gimenez A, Guembe P, de La Torre J, Bague S. Spectrum of pulmonary aspergillosis: histologic, clinical, and radiologic findings. Radiographics. 2001;21:825-37. https://doi.org/ 10.1148/radiographics.21.4.g01j103825.

74. Frat JP, Thille AW, Mercat A, Girault C, Ragot S, Perbet S, Prat G, Boulain T, Morawiec E, Cottereau A, Devaquet J, Nseir S, Razazi K, Mira JP, Argaud L, Chakarian JC, Ricard JD, Wittebole X, Chevalier S, Herbland A, Fartoukh M, Constantin JM, Tonnelier JM, Pierrot M, 
Mathonnet A, Beduneau G, Deletage-Metreau C, Richard JC, Brochard L, Robert R, FLORALI Study Group, REVA Network. High-flow oxygen through nasal cannula in acute hypoxemic respiratory failure. N Engl J Med. 2015;372:2185-96. https://doi.org/ 10.1056/NEJMoa1503326.

75. Funk DJ, Jacobsohn E, Kumar A. Role of the venous return in critical illness and shock: part II-shock and mechanical ventilation. Crit Care Med. 2013a; 41:573-9. https://doi.org/10.1097/CCM.0b013e3182 $7 \mathrm{bfc} 25$.

76. Funk DJ, Jacobsohn E, Kumar A. The role of venous return in critical illness and shock-part I: physiology. Crit Care Med. 2013b;41:255-62. https://doi.org/ 10.1097/CCM.0b013e3182772ab6.

77. Gagnadoux F, Capron F, Lebeau B. Pulmonary veno-occlusive disease after neoadjuvant mitomycin chemotherapy and surgery for lung carcinoma. Lung Cancer. 2002;36:213-5.

78. Gerritsen MG, Willemink MJ, Pompe E, van der Bruggen T, van Rhenen A, Lammers JW, Wessels F, Sprengers RW, de Jong PA, Minnema MC. Improving early diagnosis of pulmonary infections in patients with febrile neutropenia using low-dose chest computed tomography. PLoS One. 2017;12:e0172256. https://doi.org/10.1371/journal.pone.0172256.

79. Goodman LR, Fumagalli R, Tagliabue P, Tagliabue M, Ferrario M, Gattinoni L, Pesenti A. Adult respiratory distress syndrome due to pulmonary and extrapulmonary causes: CT, clinical, and functional correlations. Radiology. 1999;213:545-52. https://doi.org/10.1148/radiology.213.2.r99nv42545.

80. Grasso S, Stripoli T, De Michele M, Bruno F, Moschetta M, Angelelli G, Munno I, Ruggiero V, Anaclerio R, Cafarelli A, Driessen B, Fiore T. ARDSnet ventilatory protocol and alveolar hyperinflation: role of positive end-expiratory pressure. Am J Respir Crit Care Med. 2007;176:761-7. https://doi. org/10.1164/rccm.200702-193OC.

81. Hampshire PA, Welch CA, McCrossan LA, Francis K, Harrison DA. Admission factors associated with hospital mortality in patients with haematological malignancy admitted to UK adult, general critical care units: a secondary analysis of the ICNARC Case Mix Programme Database. Crit Care. 2009;13:R137. https://doi.org/10.1186/cc8016.

82. Hanna YM, Baglan KL, Stromberg JS, Vicini FA, Decker D. Acute and subacute toxicity associated with concurrent adjuvant radiation therapy and paclitaxel in primary breast cancer therapy. Breast J. 2002;8:149-53.

83. Harada K, Kurosawa S, Hino Y, Yamamoto K, Sakaguchi M, Ikegawa S, Hattori K, Igarashi A, Watakabe K, Senoo Y, Najima Y, Hagino T, Doki N, Kobayashi T, Kakihana K, Iino T, Sakamaki H, Ohashi K. Clinical utility of high-flow nasal cannula oxygen therapy for acute respiratory failure in patients with hematological disease.
Springerplus. 2016;5:512. https://doi.org/10.1186/ s40064-016-2161-1.

84. Hedderich GS, O'Connor RJ, Reid EC, Mulder DS. Caval tumor thrombus complicating renal cell carcinoma: a surgical challenge. Surgery. 1987;102: 614-21.

85. Heffner JE, Klein JS. Recent advances in the diagnosis and management of malignant pleural effusions. Mayo Clin Proc. 2008;83:235-50. https://doi.org/ 10.4065/83.2.235.

86. Heffner AC, Swords DS, Neale MN, Jones AE. Incidence and factors associated with cardiac arrest complicating emergency airway management. Resuscitation. 2013;84:1500-4. https://doi.org/10.10 16/j.resuscitation.2013.07.022.

87. Heussel CP, Kauczor HU, Ullmann AJ. Pneumonia in neutropenic patients. Eur Radiol. 2004;14:256-71. https://doi.org/10.1007/s00330-003-1985-6.

88. Hicks KL, Chemaly RF, Kontoyiannis DP. Common community respiratory viruses in patients with cancer: more than just "common colds". Cancer. 2003;97:2576-87. https://doi.org/10.1002/cncr.11353.

89. Hilbert G, Gruson D, Vargas F, Valentino R, GbikpiBenissan G, Dupon M, Reiffers J, Cardinaud JP. Noninvasive ventilation in immunosuppressed patients with pulmonary infiltrates, fever, and acute respiratory failure. N Engl J Med. 2001;344:481-7. https://doi.org/10.1056/NEJM200102153440703.

90. Hill QA, Kelly RJ, Patalappa C, Whittle AM, Scally AJ, Hughes A, Ashcroft AJ, Hill A. Survival of patients with hematological malignancy admitted to the intensive care unit: prognostic factors and outcome compared to unselected medical intensive care unit admissions, a parallel group study. Leuk Lymphoma. 2012;53:282-8. https://doi.org/10.3109/ 10428194.2011.614705.

91. Huisman MV, Klok FA. How I diagnose acute pulmonary embolism. Blood. 2013;121:4443-8. https:// doi.org/10.1182/blood-2013-03-453050.

92. Jacobs C, Slade M, Lavery B. Doxorubicin and BOOP. A possible near fatal association. Clin Oncol (R Coll Radiol). 2002;14:262.

93. Johkoh T, Ikezoe J, Tomiyama N, Nagareda T, Kohno N, Takeuchi N, Yamagami H, Kido S, Takashima S, Arisawa J, et al. CT findings in lymphangitic carcinomatosis of the lung: correlation with histologic findings and pulmonary function tests. AJR Am J Roentgenol. 1992;158:1217-22. https:// doi.org/10.2214/ajr.158.6.1590110.

94. Kallet RH, Diaz JV. The physiologic effects of noninvasive ventilation. Respir Care. 2009;54:102-15.

95. Kearon C, Akl EA, Comerota AJ, Prandoni P, Bounameaux H, Goldhaber SZ, Nelson ME, Wells PS, Gould MK, Dentali F, Crowther M, Kahn SR. Antithrombotic therapy for VTE disease: antithrombotic therapy and prevention of thrombosis, 9th ed: American College of Chest Physicians Evidence-Based Clinical Practice Guidelines. Chest. 
2012;141:e419S-96S. https://doi.org/10.1378/chest. 11-2301.

96. Kearon C, Akl EA, Ornelas J, Blaivas A, Jimenez D, Bounameaux H, Huisman M, King CS, Morris TA, Sood N, Stevens SM, Vintch JRE, Wells P, Woller SC, Moores L. Antithrombotic therapy for VTE disease: CHEST guideline and expert panel report. Chest. 2016;149:315-52. https://doi.org/10.1016/j.chest.20 15.11.026.

97. Keenan SP, Sinuff T, Burns KE, Muscedere J, Kutsogiannis J, Mehta S, Cook DJ, Ayas N, Adhikari NK, Hand L, Scales DC, Pagnotta R, Lazosky L, Rocker G, Dial S, Laupland K, Sanders K, Dodek P, Canadian Critical Care Trials Group/Canadian Critical Care Society Noninvasive Ventilation Guidelines Group. Clinical practice guidelines for the use of noninvasive positivepressure ventilation and noninvasive continuous positive airway pressure in the acute care setting. CMAJ. 2011;183:E195-214. https://doi.org/10.150 3/cmaj.100071.

98. Kerkering TM, Duma RJ, Shadomy S. The evolution of pulmonary cryptococcosis: clinical implications from a study of 41 patients with and without compromising host factors. Ann Intern Med. 1981; 94:611-6.

99. Khan H, Belsher J, Yilmaz M, Afessa B, Winters JL, Moore SB, Hubmayr RD, Gajic O. Fresh-frozen plasma and platelet transfusions are associated with development of acute lung injury in critically ill medical patients. Chest. 2007;131:1308-14. https://doi. org/10.1378/chest.06-3048.

100. Khilnani GC, Banga A, Sharma SK. Predictors of mortality of patients with acute respiratory failure secondary to chronic obstructive pulmonary disease admitted to an intensive care unit: a one year study. BMC Pulm Med. 2004;4:12. https://doi.org/10.1186/ 1471-2466-4-12.

101. Kim MM, Barnato AE, Angus DC, Fleisher LA, Kahn JM. The effect of multidisciplinary care teams on intensive care unit mortality. Arch Intern Med. 2010;170:369-76. https://doi.org/10.1001/archintern med.2009.521.

102. Kotloff RM, Ahya VN, Crawford SW. Pulmonary complications of solid organ and hematopoietic stem cell transplantation. Am J Respir Crit Care Med. 2004;170:22-48. https://doi.org/10.1164/rccm.2003 09-1322SO.

103. L'Her E, Deye N, Lellouche F, Taille S, Demoule A, Fraticelli A, Mancebo J, Brochard L. Physiologic effects of noninvasive ventilation during acute lung injury. Am J Respir Crit Care Med. 2005;172:1112-8. https://doi.org/10.1164/rccm.200402-226OC.

104. Lazor R, Vandevenne A, Pelletier A, Leclerc P, Court-Fortune I, Cordier JF. Cryptogenic organizing pneumonia. Characteristics of relapses in a series of 48 patients. The Groupe d'Etudes et de Recherche sur les Maladles "Orphelines" Pulmonaires (GERM“O”P). Am J Respir Crit Care
Med. 2000;162:571-7. https://doi.org/10.1164/ajrc cm.162.2.9909015.

105. Lee AY, Levine MN, Baker RI, Bowden C, Kakkar AK, Prins M, Rickles FR, Julian JA, Haley S, Kovacs MJ, Gent M, Randomized Comparison of Low-Molecular-Weight Heparin versus Oral Anticoagulant Therapy for the Prevention of Recurrent Venous Thromboembolism in Patients with Cancer (CLOT) Investigators. Low-molecularweight heparin versus a coumarin for the prevention of recurrent venous thromboembolism in patients with cancer. N Engl J Med. 2003;349:146-53. https://doi.org/10.1056/NEJMoa025313.

106. Lee HY, Rhee CK, Lee JW. Feasibility of high-flow nasal cannula oxygen therapy for acute respiratory failure in patients with hematologic malignancies: a retrospective single-center study. J Crit Care. 2015;30:773-7. https://doi.org/10.1016/j.jcrc.2015. 03.014 .

107. Lichtman MA, Rowe JM. Hyperleukocytic leukemias: rheological, clinical, and therapeutic considerations. Blood. 1982;60:279-83.

108. Lugoboni F, Faccini M, Quaglio GL, Albiero A, Casari R, Pajusco B. Intravenous flumazenil infusion to treat benzodiazepine dependence should be performed in the inpatient clinical setting for high risk of seizure. J Psychopharmacol. 2011;25:848-9. https://doi.org/10.1177/0269881110393050.

109. Makdisi G, Wang IW. Extra Corporeal Membrane Oxygenation (ECMO) review of a lifesaving technology. J Thorac Dis. 2015;7:E166-76. https://doi.org/ 10.3978/j.issn.2072-1439.2015.07.17.

110. Marchesi F, Pimpinelli F, Ensoli F, Mengarelli A. Cytomegalovirus infection in hematologic malignancy settings other than the allogeneic transplant. Hematol Oncol. 2018;36:381-91. https://doi.org/ 10.1002/hon.2453.

111. Marik PE. Aspiration pneumonitis and aspiration pneumonia. N Engl J Med. 2001;344:665-71. https://doi.org/10.1056/NEJM200103013440908.

112. Marr KA, Carter RA, Boeckh M, Martin P, Corey L. Invasive aspergillosis in allogeneic stem cell transplant recipients: changes in epidemiology and risk factors. Blood. 2002;100:4358-66. https://doi.org/ 10.1182/blood-2002-05-1496.

113. Martinez R, Reyes S, Menendez R. Pulmonary nocardiosis: risk factors, clinical features, diagnosis and prognosis. Curr Opin Pulm Med. 2008;14: 219-27. https://doi.org/10.1097/MCP.0b013e3282f $85 \mathrm{dd} 3$.

114. Maschmeyer G, Link H, Hiddemann W, Meyer P, Helmerking M, Eisenmann E, Schmitt J, Adam D. Pulmonary infiltrations in febrile patients with neutropenia. Risk factors and outcome under empirical antimicrobial therapy in a randomized multicenter study. Cancer. 1994;73:2296-304.

115. McDonald S, Rubin P, Phillips TL, Marks LB. Injury to the lung from cancer therapy: clinical syndromes, measurable endpoints, and potential scoring systems. 
Int J Radiat Oncol Biol Phys. 1995;31:1187-203. https://doi.org/10.1016/0360-3016(94)00429-O.

116. McGrath S, Chatterjee F, Whiteley C, Ostermann M. ICU and 6-month outcome of oncology patients in the intensive care unit. QJM. 2010;103:397-403. https:// doi.org/10.1093/qjmed/hcq032.

117. Mercat A, Richard JC, Vielle B, Jaber S, Osman D, Diehl JL, Lefrant JY, Prat G, Richecoeur J, Nieszkowska A, Gervais C, Baudot J, Bouadma L, Brochard L, Expiratory Pressure (Express) Study Group. Positive end-expiratory pressure setting in adults with acute lung injury and acute respiratory distress syndrome: a randomized controlled trial. JAMA. 2008;299:646-55. https://doi.org/10.1001/ jama.299.6.646.

118. Metheny NA, Clouse RE, Chang YH, Stewart BJ, Oliver DA, Kollef MH. Tracheobronchial aspiration of gastric contents in critically ill tube-fed patients: frequency, outcomes, and risk factors. Crit Care Med. 2006;34:1007-15. https://doi.org/10.1097/01.CCM.0 000206106.65220 .59 .

119. Meyer G, Vicaut E, Danays T, Agnelli G, Becattini C, Beyer-Westendorf J, Bluhmki E, Bouvaist $\mathrm{H}$, Brenner B, Couturaud F, Dellas C, Empen K, Franca A, Galie N, Geibel A, Goldhaber SZ, Jimenez D, Kozak M, Kupatt C, Kucher N, Lang IM, Lankeit M, Meneveau N, Pacouret G, Palazzini M, Petris A, Pruszczyk P, Rugolotto M, Salvi A, Schellong S, Sebbane M, Sobkowicz B, Stefanovic BS, Thiele H, Torbicki A, Verschuren F, Konstantinides SV, PEITHO Investigators. Fibrinolysis for patients with intermediate-risk pulmonary embolism. N Engl J Med. 2014;370:1402-11. https://doi.org/10.1056/NEJMoa1302097.

120. Mismetti P, Laporte S, Pellerin O, Ennezat PV, Couturaud F, Elias A, Falvo N, Meneveau N, Quere I, Roy PM, Sanchez O, Schmidt J, Seinturier C, Sevestre MA, Beregi JP, Tardy B, Lacroix P, Presles E, Leizorovicz A, Decousus H, Barral FG, Meyer G, PREPIC2 Study Group. Effect of a retrievable inferior vena cava filter plus anticoagulation vs anticoagulation alone on risk of recurrent pulmonary embolism: a randomized clinical trial. JAMA. 2015;313:1627-35. https://doi.org/ 10.1001/jama.2015.3780.

121. Miwa S, Morita S, Suda T, Suzuki K, Hayakawa H, Chida K, Nakamura H. The incidence and clinical characteristics of bronchiolitis obliterans organizing pneumonia syndrome after radiation therapy for breast cancer. Sarcoidosis Vasc Diffuse Lung Dis. 2004;21:212-8.

122. Molina R, Bernal T, Borges M, Zaragoza R, Bonastre J, Granada RM, Rodriguez-Borregan JC, Nunez K, Seijas I, Ayestaran I, Albaiceta GM. Ventilatory support in critically ill hematology patients with respiratory failure. Crit Care. 2012;16:R133. https://doi.org/10.1186/cc11438. cc11438 [pii].

123. Mosier JM, Joshi R, Hypes C, Pacheco G, Valenzuela T, Sakles JC. The physiologically difficult airway. West J Emerg Med. 2015a;16:1109-17. https://doi.org/10.5811/westjem.2015.8.27467.

124. Mosier JM, Hypes C, Joshi R, Whitmore S, Parthasarathy S, Cairns CB. Ventilator strategies and rescue therapies for management of acute respiratory failure in the emergency department. Ann Emerg Med. 2015b;66:529-41. https://doi.org/ 10.1016/j.annemergmed.2015.04.030.

125. Moskovic E, Miller R, Pearson M. High resolution computed tomography of Pneumocystis carinii pneumonia in AIDS. Clin Radiol. 1990;42:239-43.

126. Movsas B, Raffin TA, Epstein AH, Link CJ Jr. Pulmonary radiation injury. Chest. 1997;111: 1061-76.

127. Mullins PM, Goyal M, Pines JM. National growth in intensive care unit admissions from emergency departments in the United States from 2002 to 2009. Acad Emerg Med. 2013;20:479-86. https://doi.org/ 10.1111/acem.12134.

128. Muraoka M, Tagawa T, Akamine S, Oka T, Tsuchiya T, Araki M, Hayashi T, Nagayasu T. Acute interstitial pneumonia following surgery for primary lung cancer. Eur J Cardiothorac Surg. 2006;30: 657-62. https://doi.org/10.1016/j.ejcts.2006.06.020.

129. Naidoo J, Wang X, Woo KM, Iyriboz T, Halpenny D, Cunningham J, Chaft JE, Segal NH, Callahan MK, Lesokhin AM, Rosenberg J, Voss MH, Rudin CM, Rizvi H, Hou X, Rodriguez K, Albano M, Gordon RA, Leduc C, Rekhtman N, Harris B, Menzies AM, Guminski AD, Carlino MS, Kong BY, Wolchok JD, Postow MA, Long GV, Hellmann MD. Pneumonitis in patients treated with anti-programmed death-1/programmed death ligand 1 therapy. J Clin Oncol. 2017;35:709-17. https://doi.org/10.1200/ JCO.2016.68.2005.

130. Nassar AP Jr, Dettino ALA, Amendola CP, Dos Santos RA, Forte DN, Caruso P. Oncologists' and intensivists' attitudes toward the care of critically ill patients with cancer. J Intensive Care Med. 2017; 885066617716105. https://doi.org/10.1177/0885066 617716105 .

131. Ozkan M, Dweik RA, Ahmad M. Drug-induced lung disease. Cleve Clin J Med. 2001;68:782-5, 789-95.

132. Pappas PG, Perfect JR, Cloud GA, Larsen RA, Pankey GA, Lancaster DJ, Henderson H, Kauffman CA, Haas DW, Saccente M, Hamill RJ, Holloway MS, Warren RM, Dismukes WE. Cryptococcosis in human immunodeficiency virus-negative patients in the era of effective azole therapy. Clin Infect Dis. 2001;33:690-9. https://doi. org/10.1086/322597.

133. Pastores SM, Voigt LP. Acute respiratory failure in the patient with cancer: diagnostic and management strategies. Crit Care Clin. 2010;26:21-40. https://doi.org/ 10.1016/j.ccc.2009.10.001.

134. Paz HL, Crilley P, Weinar M, Brodsky I. Outcome of patients requiring medical ICU admission following bone marrow transplantation. Chest. 1993;104: 527-31. S0012-3692(16)35370-3 [pii]. 
135. Perbet S, De Jong A, Delmas J, Futier E, Pereira B, Jaber S, Constantin JM. Incidence of and risk factors for severe cardiovascular collapse after endotracheal intubation in the ICU: a multicenter observational study. Crit Care. 2015;19:257. https://doi.org/ 10.1186/s13054-015-0975-9.

136. Pfeifer R, Heussen N, Michalewicz E, Hilgers RD, Pape HC. Incidence of adult respiratory distress syndrome in trauma patients: a systematic review and meta-analysis over a period of three decades. J Trauma Acute Care Surg. 2017;83:496-506. https://doi.org/10.1097/TA.0000000000001571.

137. Picano E, Pellikka PA. Ultrasound of extravascular lung water: a new standard for pulmonary congestion. Eur Heart J. 2016;37:2097-104. https://doi.org/ 10.1093/eurheartj/ehw164.

138. Pisani RJ, Wright AJ. Clinical utility of bronchoalveolar lavage in immunocompromised hosts. Mayo Clin Proc. 1992;67:221-7.

139. Pishgar F, Ebrahimi H, Saeedi Moghaddam S, Fitzmaurice C, Amini E. Global, regional and national burden of prostate cancer, 1990 to 2015: results from the Global Burden of Disease Study 2015. J Urol. 2018;199:1224-32. https://doi.org/ 10.1016/j.juro.2017.10.044.

140. Primack SL, Miller RR, Muller NL. Diffuse pulmonary hemorrhage: clinical, pathologic, and imaging features. AJR Am J Roentgenol. 1995;164:295-300. https://doi.org/10.2214/ajr.164.2.7839958.

141. Prin M, Wunsch H. International comparisons of intensive care: informing outcomes and improving standards. Curr Opin Crit Care. 2012;18:700-6. https://doi.org/10.1097/MCC.0b013e32835914d5.

142. Pulte D, Gondos A, Brenner H. Expected longterm survival of patients diagnosed with acute myeloblastic leukemia during 2006-2010. Ann Oncol. 2010;21:335-41. https://doi.org/10.1093/annonc/md p309.

143. Rabello LS, Silva JR, Azevedo LC, Souza I, Torres VB, Rosolem MM, Lisboa T, Soares M, Salluh JI. Clinical outcomes and microbiological characteristics of severe pneumonia in cancer patients: a prospective cohort study. PLoS One. 2015;10:e0120544. https://doi.org/10.1371/journal. pone.0120544. PONE-D-14-35125 [pii].

144. Rahman NM, Chapman SJ, Davies RJ. Pleural effusion: a structured approach to care. $\mathrm{Br}$ Med Bull. 2004;72:31-47. https://doi.org/10.1093/bmb/ldh040.

145. Reichner CA, Thompson JA, O’Brien S, Kuru T, Anderson ED. Outcome and code status of lung cancer patients admitted to the medical ICU. Chest. 2006;130:719-23. https://doi.org/10.1378/chest.130. 3.719 .

146. Rochwerg B, Brochard L, Elliott MW, Hess D, Hill NS, Nava S, Navalesi P Members of the Steering Committee, Antonelli M, Brozek J, Conti G, Ferrer M, Guntupalli K, Jaber S, Keenan S, Mancebo J, Mehta S, Raoof S Members of the Task Force. Official ERS/ATS clinical practice guidelines: noninvasive ventilation for acute respiratory failure. Eur Respir J. 2017;50. https://doi.org/10.1183/13993 003.02426-2016.

147. Rosenow EC 3rd, Limper AH. Drug-induced pulmonary disease. Semin Respir Infect. 1995;10:86-95.

148. Roychowdhury DF, Cassidy CA, Peterson P, Arning M. A report on serious pulmonary toxicity associated with gemcitabine-based therapy. Invest New Drugs. 2002;20:311-5.

149. Rutherford JD. Digital clubbing. Circulation. 2013; 127:1997-9. https://doi.org/10.1161/CIRCULATIO NAHA.112.000163.

150. Ryu JH. Chemotherapy-induced pulmonary toxicity in lung cancer patients. J Thorac Oncol. 2010;5: 1313-4. https://doi.org/10.1097/JTO.0b013e3181e9 dbb9.

151. Schapira DV, Studnicki J, Bradham DD, Wolff P, Jarrett A. Intensive care, survival, and expense of treating critically ill cancer patients. JAMA. 1993;269:783-6.

152. Schellongowski P, Sperr WR, Wohlfarth P, Knoebl P, Rabitsch W, Watzke HH, Staudinger T. Critically ill patients with cancer: chances and limitations of intensive care medicine-a narrative review. ESMO Open. 2016;1:e000018. https://doi.org/10.1136/esm oopen-2015-000018.

153. Schnell D, Mayaux J, Lambert J, Roux A, Moreau AS, Zafrani L, Canet E, Lemiale V, Darmon M, Azoulay E. Clinical assessment for identifying causes of acute respiratory failure in cancer patients. Eur Respir J. 2013;42:435-43. https:// doi.org/10.1183/09031936.00122512.

154. Shah DP, Shah PK, Azzi JM, El Chaer F, Chemaly RF. Human metapneumovirus infections in hematopoietic cell transplant recipients and hematologic malignancy patients: a systematic review. Cancer Lett. 2016;379: 100-6. https://doi.org/10.1016/j.canlet.2016.05.035.

155. Siegel RL, Miller KD, Jemal A. Cancer statistics, 2017. CA Cancer J Clin. 2017;67:7-30. https://doi. org/10.3322/caac. 21387.

156. Silliman CC, Ambruso DR, Boshkov LK. Transfusion-related acute lung injury. Blood. 2005; 105:2266-73. https://doi.org/10.1182/blood-200407-2929.

157. Silverberg E, Holleb AI. Major trends in cancer: 25 year survey. CA Cancer J Clin. 1975;25:2-8.

158. Snyder LS, Hertz MI. Cytotoxic drug-induced lung injury. Semin Respir Infect. 1988;3:217-28.

159. Soares M, Salluh JI, Spector N, Rocco JR. Characteristics and outcomes of cancer patients requiring mechanical ventilatory support for $>24 \mathrm{hrs}$. Crit Care Med. 2005;33:520-6. 00003246-20050300000008 [pii].

160. Soares M, Darmon M, Salluh JIF, Ferreira CG, Thiery G, Schlemmer B, Spector N, Azoulay E. Prognosis of lung cancer patients with life-threatening complications. Chest. 2007;131:840-6. https://doi. org/10.1378/chest.06-2244. 
161. Soares M, Depuydt PO, Salluh JI. Mechanical ventilation in cancer patients: clinical characteristics and outcomes. Crit Care Clin. 2010a;26:41-58. https:// doi.org/10.1016/j.ccc.2009.09.005. S0749-0704(09) 00078-5 [pii].

162. Soares M, Caruso P, Silva E, Teles JM, Lobo SM, Friedman G, Dal Pizzol F, Mello PV, Bozza FA, Silva UV, Torelly AP, Knibel MF, Rezende E, Netto JJ, Piras C, Castro A, Ferreira BS, Rea-Neto A, Olmedo PB, Salluh JI. Characteristics and outcomes of patients with cancer requiring admission to intensive care units: a prospective multicenter study. Crit Care Med. 2010b;38:9-15. https://doi.org/ 10.1097/CCM.0b013e3181c0349e.

163. Sohn JW. Acute eosinophilic pneumonia. Tuberc Respir Dis (Seoul). 2013;74:51-5. https://doi.org/ 10.4046/trd.2013.74.2.51.

164. Solis A, Baillard C. Effectiveness of preoxygenation using the head-up position and noninvasive ventilation to reduce hypoxaemia during intubation. Ann Fr Anesth Reanim. 2008;27:490-4. https://doi.org/ 10.1016/j.annfar.2008.04.006.

165. Springmeyer SC. The clinical use of bronchoalveolar lavage. Chest. 1987;92:771-2.

166. Stefan MS, Shieh MS, Pekow PS, Rothberg MB, Steingrub JS, Lagu T, Lindenauer PK. Epidemiology and outcomes of acute respiratory failure in the United States, 2001 to 2009: a national survey. J Hosp Med. 2013;8:76-82. https://doi.org/10.1002/ jhm.2004.

167. Stemmelin GR, Bernaciak J, Casas JG. Bronchiolitis with leukemia. Ann Intern Med. 1991;114:912-3.

168. Stover DE, Kaner RJ. Pulmonary complications in cancer patients. CA Cancer J Clin. 1996;46:303-20.

169. Taccone FS, Artigas AA, Sprung CL, Moreno R, Sakr Y, Vincent JL. Characteristics and outcomes of cancer patients in European ICUs. Crit Care. 2009;13: R15. https://doi.org/10.1186/cc7713.

170. Takigawa N, Segawa Y, Saeki T, Kataoka M, Ida M, Kishino D, Fujiwara K, Ohsumi S, Eguchi K, Takashima S. Bronchiolitis obliterans organizing pneumonia syndrome in breast-conserving therapy for early breast cancer: radiation-induced lung toxicity. Int J Radiat Oncol Biol Phys. 2000;48:751-5.

171. Tamura M, Saraya T, Fujiwara M, Hiraoka S, Yokoyama T, Yano K, Ishii H, Furuse J, Goya T, Takizawa H, Goto H. High-resolution computed tomography findings for patients with drug-induced pulmonary toxicity, with special reference to hypersensitivity pneumonitis-like patterns in gemcitabineinduced cases. Oncologist. 2013;18:454-9. https:// doi.org/10.1634/theoncologist.2012-0248.

172. Tanoubi I, Drolet P, Donati F. Optimizing preoxygenation in adults. Can J Anaesth. 2009;56: 449-66. https://doi.org/10.1007/s12630-009-9084-z.

173. Teller LE, Alexander CM, Frumin MJ, Gross JB. Pharyngeal insufflation of oxygen prevents arterial desaturation during apnea. Anesthesiology. 1988; 69:980-2.
174. Thun MJ, DeLancey JO, Center MM, Jemal A, Ward EM. The global burden of cancer: priorities for prevention. Carcinogenesis. 2010;31:100-10. https://doi.org/10.1093/carcin/bgp263.

175. Timp JF, Braekkan SK, Versteeg HH, Cannegieter SC. Epidemiology of cancer-associated venous thrombosis. Blood. 2013;122:1712-23. https://doi.org/10.1182/blood-2013-04-460121.

176. Torre LA, Siegel RL, Ward EM, Jemal A. Global cancer incidence and mortality rates and trends an update. Cancer Epidemiol Biomarkers Prev. 2016;25:16-27. https://doi.org/10.1158/1055-9965. EPI-15-0578.

177. Torres A, Puig de la Bellacasa J, Xaubet A, Gonzalez J, Rodriguez-Roisin R, Jimenez de Anta MT, Agusti Vidal A. Diagnostic value of quantitative cultures of bronchoalveolar lavage and telescoping plugged catheters in mechanically ventilated patients with bacterial pneumonia. Am Rev Respir Dis. 1989;140:306-10. https://doi.org/ 10.1164/ajrccm/140.2.306.

178. Torres HA, Reddy BT, Raad II, Tarrand J, Bodey GP, Hanna HA, Rolston KV, Kontoyiannis DP. Nocardiosis in cancer patients. Medicine (Baltimore). 2002;81:388-97.

179. Toy P, Popovsky MA, Abraham E, Ambruso DR, Holness LG, Kopko PM, McFarland JG, Nathens AB, Silliman CC, Stroncek D, National Heart, Lung and Blood Institute Working Group on TRALI. Transfusion-related acute lung injury: definition and review. Crit Care Med. 2005;33:721-6.

180. Vilchez RA, Linden P, Lacomis J, Costello P, Fung J, Kusne S. Acute respiratory failure associated with pulmonary cryptococcosis in non-aids patients. Chest. 2001;119:1865-9.

181. Walkey AJ, Wiener RS. Use of noninvasive ventilation in patients with acute respiratory failure, 2000-2009: a population-based study. Ann Am Thorac Soc. 2013;10:10-7. https://doi.org/10.1513/ AnnalsATS.201206-0340C.

182. Walz JM, Zayaruzny M, Heard SO. Airway management in critical illness. Chest. 2007;131:608-20. https://doi.org/10.1378/chest.06-2120.

183. Weingart SD. Preoxygenation, reoxygenation, and delayed sequence intubation in the emergency department. J Emerg Med. 2011;40:661-7. https://doi.org/ 10.1016/j.jemermed.2010.02.014.

184. Wermke M, Schiemanck S, Hoffken G, Ehninger G, Bornhauser M, Illmer T. Respiratory failure in patients undergoing allogeneic hematopoietic SCT a randomized trial on early non-invasive ventilation based on standard care hematology wards. Bone Marrow Transplant. 2012;47:574-80. https://doi.org/ 10.1038/bmt.2011.160.

185. Writing Group for the Alveolar Recruitment for Acute Respiratory Distress Syndrome Trial (ART) Investigators, Cavalcanti AB, Suzumura EA, Laranjeira LN, Paisani DM, Damiani LP, Guimaraes HP, Romano ER, Regenga MM, Taniguchi LNT, 
Teixeira C, Pinheiro de Oliveira R, Machado FR, Diaz-Quijano FA, Filho MSA, Maia IS, Caser EB, Filho WO, Borges MC, Martins PA, Matsui M, Ospina-Tascon GA, Giancursi TS, GiraldoRamirez ND, Vieira SRR, Assef M, Hasan MS, Szczeklik W, Rios F, Amato MBP, Berwanger O, Ribeiro de Carvalho CR. Effect of lung recruitment and titrated positive end-expiratory pressure (PEEP) vs low PEEP on mortality in patients with acute respiratory distress syndrome: a randomized clinical trial. JAMA. 2017;318:1335-45. https://doi.org/ 10.1001/jama.2017.14171.

186. Wun T, White RH. Epidemiology of cancer-related venous thromboembolism. Best Pract Res Clin Haematol. 2009;22:9-23. https://doi.org/10.1016/j. beha.2008.12.001.
187. Yale SH, Limper AH. Pneumocystis carinii pneumonia in patients without acquired immunodeficiency syndrome: associated illness and prior corticosteroid therapy. Mayo Clin Proc. 1996;71:5-13.

188. Yamashita H, Nakagawa K, Nakamura N, Koyanagi H, Tago M, Igaki H, Shiraishi K, Sasano N, Ohtomo K. Exceptionally high incidence of symptomatic grade 2-5 radiation pneumonitis after stereotactic radiation therapy for lung tumors. Radiat Oncol. 2007;2:21. https://doi.org/10.1186/ 1748-717X-2-21.

189. Zhang LJ, Hanff P, Rutherford C, Churchill WH, Crumpacker CS. Detection of human cytomegalovirus DNA, RNA, and antibody in normal donor blood. J Infect Dis. 1995;171:1002-6. 